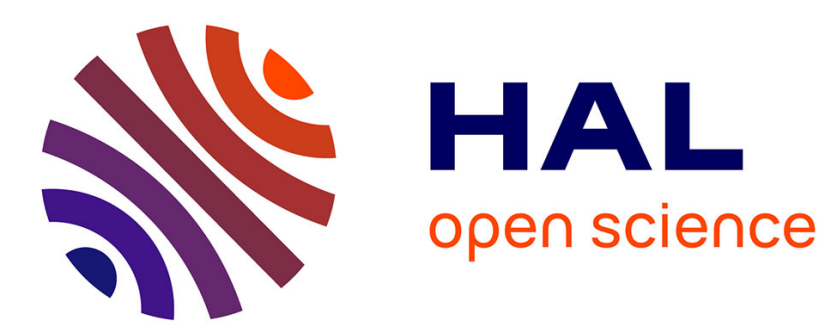

\title{
The Rheology and Morphology of Oceanic Lithosphere and Mid-Ocean Ridges
}

R. C. Searle, J. Escartin

\section{To cite this version:}

R. C. Searle, J. Escartin. The Rheology and Morphology of Oceanic Lithosphere and Mid-Ocean Ridges. C.R. German; J. Lin; L.M. Parson. Mid Ocean Ridges. Hydrothermal interactions between the lithosphere and the oceans, 148, American Geophysical Union, pp.63-93, 2013, Geophysical Monograph Series, 9780875904139. 10.1029/148GM03 . hal-02330198

\section{HAL Id: hal-02330198 \\ https://hal.science/hal-02330198}

Submitted on 23 Oct 2019

HAL is a multi-disciplinary open access archive for the deposit and dissemination of scientific research documents, whether they are published or not. The documents may come from teaching and research institutions in France or abroad, or from public or private research centers.
L'archive ouverte pluridisciplinaire HAL, est destinée au dépôt et à la diffusion de documents scientifiques de niveau recherche, publiés ou non, émanant des établissements d'enseignement et de recherche français ou étrangers, des laboratoires publics ou privés. 


\title{
The Rheology and Morphology of Oceanic Lithosphere and Mid-Ocean Ridges
}

\author{
R. C. Searle \\ Department of Earth Sciences, University of Durham, UK \\ J. Escartín \\ Laboratoire de Géosciences Marines (CNRS UMR7097), Institut de Physique du Globe de Paris, \\ France
}

The rheology of oceanic lithosphere is primarily a function of temperature, the abundance and distribution of lithologies and fluids, and their mechanical properties. Rheology controls the overall strength and mode of deformation. Seafloor morphology is the surface expression of this deformation, modified by additional processes such as volcanism. Rheological models are key to interpreting both naturally deformed rocks as direct indicators of deformation conditions and the resulting morphology. Simple thermo-mechanical models have proven useful to study ridge processes, but are limited by lack of knowledge of lithospheric architecture, composition, and rheology.

The mechanical properties of some components (olivine, dolerite, olivine plus melt, serpentinite) are reasonably known, but must be extended to other important materials such as alteration products and include the role of fluids and compositional variations. While the overall composition of oceanic lithosphere is relatively well known, particularly for fast-spreading ridges, the distribution and abundance of melt and alteration products is not. Though sparse, these weak phases can strongly control the overall strength, mode and localization of deformation.

Thermo-mechanical models successfully reproduce observed axial relief and general faulting patterns. They provide plausible mechanisms of lithospheric behavior, but cannot constrain actual deformation processes. In particular, they must assume rheology, thermal structure, and composition and distribution of materials, and are non-unique. The most accurate constraints on rheology and deformation processes will come from study of naturally deformed rocks. This will guide the choice of the models used to interpret morphology and infer the detailed thermal structure under ridges.

Book Title

Book Series

Copyright 2004 by the American Geophysical Union

10.1029/Series\#LettersChapter\#

\section{INTRODUCTION}

The subject of the first InterRidge Theoretical Institute in Pavia, Italy, 2002, was the "Thermal regime of oceanic ridges and dynamics of hydrothermal circulation". There is a fundamental, though complex, connection between ridge mor- 
phology and the rheology and thermal regime of the lithosphere, which we review here.

At the largest scale, the shape of the mid-ocean ridge itself is defined by the thermal contraction of the lithosphere created at the ridge [Parsons and Sclater, 1977]. The lithosphere can then be deformed continuously by elastic flexure in response to applied loads such as seamounts, ocean islands, fracture zones, and subduction zones [Watts, 1978]. The flexural response itself depends on the rheology of the lithosphere, which in turn is a function of lithospheric temperature [McNutt, 1984]. At a smaller scale, the lithosphere may be deformed discontinuously when a fault forms [Atwater and Mudie, 1968; Ballard and Van Andel, 1977]. The mechanics of faulting also depends strongly on the rheology of the rock, including its strength and the coefficient of friction on the fault, all of which may be strongly dependent on temperature, pressure and fluid content, among other parameters. Moreover, the loads resulting from faulting may cause further lithospheric flexure [Bott, 1996; Buck, 1988; Weissel and Karner, 1989]. The distribution, spacing, and size of faults may be controlled by and provide an indication of the lithospheric thickness and rheology [Shaw, 1992].

To fully describe and accurately model the processes occurring at mid-ocean ridges, therefore, we need a good understanding and parameterization of the rheology of the lithosphere. This can be approached by a combination of laboratory experiments and observations on actual deformed rocks. Alternatively, we might take observations on ridge morphology and other parameters, and attempt to invert them to determine the underlying rheology and temperature. However, given the complexities in the structures and processes involved, this link is still weak. In practice, a combined approach is necessary.

In this paper, we will review current experimental and field work on the rheology of the lithosphere or its components. We will also review the morphology of mid-ocean ridges and what can be inferred about from it concerning their rheology and underlying temperature structure.

\section{RHEOLOGY OF THE OCEANIC LITHOSPHERE}

\subsection{The Strength of the Lithosphere}

Experimental studies have revealed the physical mechanisms responsible for deformation in the lithosphere and provide constitutive equations to describe its mechanical behavior (see reviews by [Kirby, 1983] and [Kohlstedt et al., 1995]). Early studies revealed that, to a first approximation, rocks deform in one of two ways: by brittle failure at low temperatures and pressures (shallow depths), and by ductile or plastic deformation at higher temperatures and/or pressures, e.g.,
[Byerlee, 1968; Byerlee, 1978; Goetze, 1978]. From experimental constraints on the strength of rocks at different temperature and pressure conditions, and assuming a simple lithology, a yield envelope for the whole lithosphere can be calculated, as we discuss below [Brace and Kohlstedt, 1980; Goetze and Evans, 1979; Kirby, 1983; Kohlstedt et al., 1995] (Figure 1). These simple models provided a means to directly correlate rock properties with lithospheric thickness inferred from geophysical data (e.g., gravity, bathymetry, seismicity), but ignored the mode of deformation within the lithosphere and the rheological effects of parameters such as water or lithological heterogeneity.

In this approach, the mantle is modeled assuming the rheology measured for single crystals or aggregates of olivine crystals [Chopra, 1986; Chopra and Paterson, 1984; Durham and Goetze, 1977; Durham et al., 1977; Evans and Goetze, 1979; Kohlstedt and Goetze, 1974]. For the oceanic crust, the rheology of diabase as determined in the laboratory [Agar and Marton, 1995; Caristan, 1982; Mackwell et al., 1998; Shelton and Tullis, 1981] is assumed to apply to all rocks that compose the magmatic crust (i.e., gabbro, diabase and basalt), as these rocks are compositionally similar [Goetze and Evans, 1979; Kohlstedt et al., 1995]. 'Classical' rheological models have assumed that the plastic flow law for the crust (diabase)

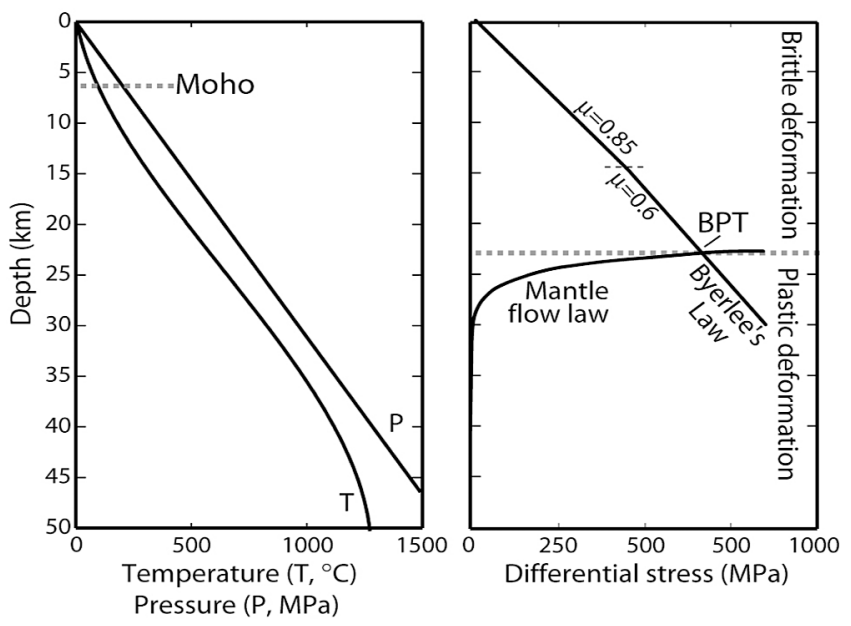

Figure 1. Left: variation in confining pressure $(\mathrm{P})$ and temperature (T) with depth; right: corresponding yield strength envelope. The shallow levels deform in the brittle regime, where the maximum strength is given by Byerlee's friction law. The brittle domain overlies a plastic domain where deformation is accommodated by creep, and shows a fast decrease in the yield strength with increasing temperature and depth. The transition between the two regimes, where strength is maximum, corresponds to the brittle-plastic transition (BPT). The relative position of the Moho (6-km oceanic crustal thickness) is also indicated in the left panel. Calculations are for a strain rate of $\sim 10-15 \mathrm{~s}-1$. 
is much weaker than that of the mantle (olivine), resulting in a decoupling weak lower crust under the ridge axis (Figure 2) [Chen and Morgan, 1990a; Shaw and Lin, 1996]. More recent experimental work shows that these models need to be revised, as the strength of dry crust may be similar to that of the mantle (Figure 3) [Hirth and Kohlstedt, in press; Mackwell et al., 1998].

Being more complex, the continental crust is commonly modeled assuming a layered structure and using the rheology of quartz [Blacic and Christie, 1984; Jaoul et al., 1984; Kronenberg and Tullis, 1984; Mainprice and Paterson, 1984], calcite [Fredrich et al., 1989], and granite [Tullis and Yund, 1977]. More recently, experimental work has been extended to other rocks found in the lithosphere, such as serpentinite and serpentinized peridotite [Escartin et al., 2001; Escartin et al., 1997b; Reinen et al., 1994], micas [Mares and Kronenberg, 1993; Shea and Kronenberg, 1992; Shea and Kronenberg, 1993], and feldspar [Rybacki and Dresen, 2000; Tullis and Yund, 1991], among other lithologies. In addition, numerous studies demonstrate that the presence of water [Hirth and Kohlstedt, 1996; Karato et al., 1986; Mainprice and Paterson, 1984; Tullis and Yund, 1989], and melt [Hirth and Kohlstedt, 1995a; Hirth and Kohlstedt, 1995b], can have very signifi-

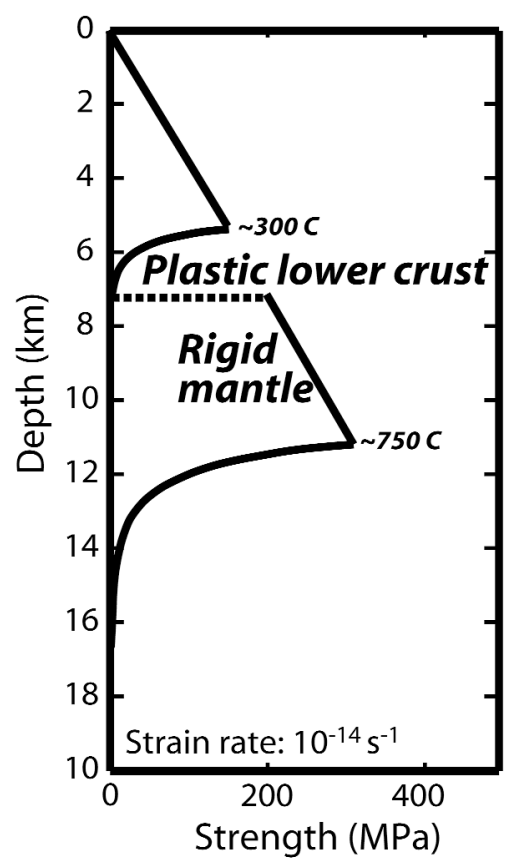

Figure 2. Yield strength envelope used in thermo-mechanical models, displaying a plastic lower crust decoupled from the mantle. These models have a brittle to plastic transition at a very low temperature $\left(<400^{\circ} \mathrm{C}\right)$ [Chen and Morgan, 1990a]. These models used a wet diabase rheology for the plastic strength of the crust, which is now known to be unrealistic.

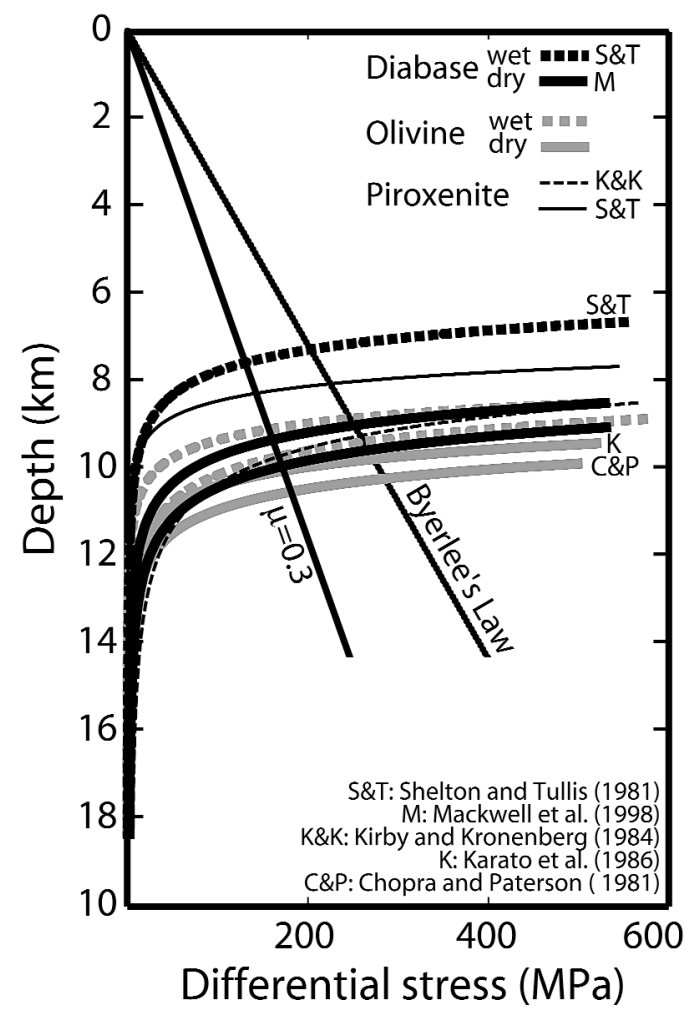

Figure 3. Plot of plastic flow laws for different lithologies and water content (curves) and predicted frictional strength in the brittle regime (straight lines) for a coefficient of friction for Byerlee's friction law (? 0.85) and for serpentinite (? 0.3) [Escartin et al., 1997b]. Flow laws are shown for diabase (thick black lines) [Mackwell et al., 1998; Shelton and Tullis, 1981], olivine (thick grey lines) [Chopra, 1986; Karato et al., 1986] and pyroxenite (thin black lines) [Kirby and Kronenberg, 1984; Shelton and Tullis, 1981].

cant effects on the rheology of the mantle and the crust, as discussed below.

\subsection{Brittle Deformation}

In the brittle regime, initial deformation is instantaneous and elastic. When the stresses exceed a yield point, brittle failure occurs. The maximum strength of the rock is dependant on the pressure, following a Coulomb law of the form:

$$
\tau=c+\mu \sigma_{\mathrm{n}}
$$

where $\tau$ is the shear stress, $c$ is a material constant, $\mu$ is the coefficient of friction, and $\sigma_{n}$ is the normal stress on the failing fault plane. As the lithosphere is assumed to be fractured, $c$ is $\sim 0 \mathrm{MPa}$, and the strength increases linearly with confining pressure and thus depth. [Byerlee, 1978] illustrated that for many rocks, strength is independent of composition. Thus a 
'universal friction law' (known as Byerlee's friction law) could be used:

$$
\mathrm{c}=0 \mathrm{MPa}, \mu=0.85, \quad \text { for } \sigma_{\mathrm{n}}<200 \mathrm{MPa},
$$

and

$$
\mathrm{c}=60 \mathrm{MPa}, \mu=0.6, \quad \text { for } \sigma_{\mathrm{n}}<200 \mathrm{MPa} .
$$

While this parameterization of the strength in the brittle regime has been widely used to model the lithosphere, [Byerlee, 1978] and more recent experimental work has demonstrated that there can be important variations in the frictional characteristics of different materials. For example, the coefficient of friction for the serpentine polymorph lizardite, which is the most abundant form in the oceanic lithosphere, is $\mu \sim 0.35$ [Escartin et al., 1997b], and slightly serpentinized peridotites show a similar behavior to that of pure serpentinite [Escartín et al., 2001]. Serpentine may be an abundant component of the oceanic lithosphere, and therefore its presence can have a substantial weakening effect when incorporated into yield envelopes (Figures 1 and 3). As the modeled brittle strength of the lithosphere increases linearly with overburden pressure and thus depth, small variations in the coefficient of friction can result in large strength variations.

\subsection{Plastic Deformation}

Plastic deformation is accommodated by solid state creep [Goetze, 1978] according to:

$$
\dot{\varepsilon}=A \sigma^{n} d^{m} e^{-Q / R T}
$$

where $\dot{\varepsilon}$ is the strain rate, $\sigma$ is the differential stress, $d$ is the grain size, $R$ is the universal gas constant, and $A, Q, n$ and $m$ are constants that are specific to each material and can be determined experimentally.

Because of the exponential term, the strain rate increases rapidly with increasing temperature for a given applied stress. This is equivalent to an exponential reduction in mantle strength with increasing depth, given a constant stress and strain rate (Figure 1). The crossing point between the frictional and the plastic strength is considered to mark the brittle-to-plastic transition (BPT), and is also where the strongest lithosphere is found at depth (Figure 1). The BPT is located close to the base of the mechanical lithosphere, which is defined as the depth at which the strength is a small fraction of the ambient stress-difference. The depth at which this occurs depends, among other factors, on the strain rate, and therefore varying lithospheric thicknesses may be expected at different time scales or for processes occurring at different rates. For reasonable geological strain rate values $\left(10^{-15}-10^{-18} \mathrm{~s}^{-1}\right)$ this transition occurs at $\sim 750^{\circ} \mathrm{C}$.

Plastic deformation can be accommodated by two creep mechanisms (Figure 4). The first, known as diffusion creep, is characterized by mobilization of atoms around grain boundaries and is limited by the rate of grain-boundary diffusion. When this mechanism operates, the strain rate varies linearly with stress $(n \sim 1)$. The second mechanism, known as dislocation creep, accommodates crystal deformation by the propagation of crystal defects (dislocations). In the dislocation creep regime, which tends to occur at larger grain sizes, the strain rate depends non-linearly on the applied stress $(n \sim 3)$ [Karato et al., 1986]. Dislocation creep can also result in the formation of new grains and sub grains, reducing the overall grain size of the rock, and promoting a transition in creep

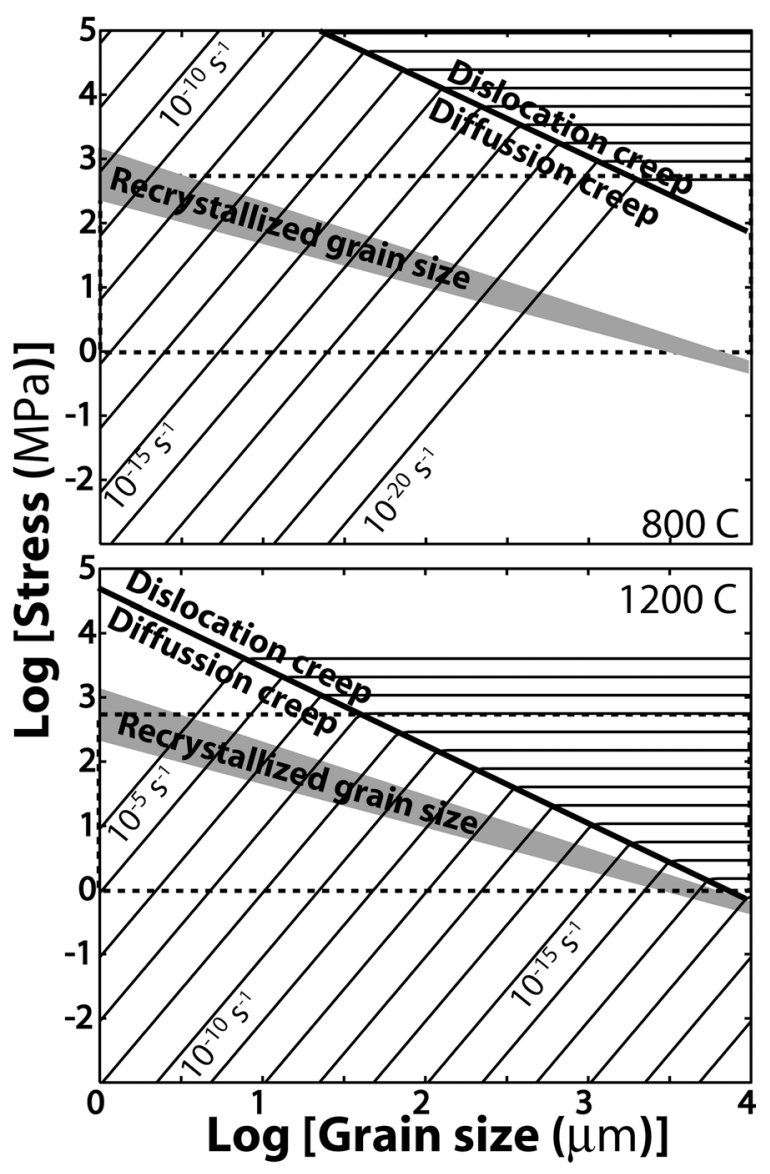

Figure 4. Maps of creep deformation for olivine mylonites, showing the variation in strain rate as a function of grain size and differential stress, for two temperatures as indicated. The bounds of geological stresses are indicated by the dashed lines. The shaded area gives the predicted grain size - stress relationship [Van der Wal, 1993]. Note that dislocation creep is activated at lower stresses and smaller grain sizes with increasing temperatures. After [Jaroslow et al., 1996]. 
mechanism from dislocation creep to diffusion creep [Hirth, 2002; Jaroslow et al., 1996].

\subsection{The Effects of Composition, Grain Size, Water and Melt}

Rock strength is determined by the composition of the rock (mineralogy), by the presence of fluids (e.g., water and melt), and by the stress and temperature conditions. While most experimental work is carried out in mono-mineralic rocks, natural rocks are composed of several mineralogical phases. [Mackwell et al., 1998] showed that two types of diabase with different ratios of pyroxene and plagioclase have similar power law relationships (i.e., similar values for $n$ and $Q$ ) but different strengths (as the measured $A$ changed by a factor of 20). Figure 3 shows the variations in predicted strength for olivine, diabase and pyroxenite; depending on rock type, the thickness of the lithosphere could vary by more than $4 \mathrm{~km}$ near the mid-ocean ridge axis, with large variations of the maximum strength at the BPT. Therefore, knowledge of the composition and distribution of lithologies is necessary to construct accurate rheological models of the lithosphere, in addition to experimental and theoretical work on the rheology of polyphase materials [Tullis and Yund, 1991].

Water content is a second parameter that can strongly modify the overall strength of lithospheric materials (Figures 3 and 5) [Hirth, 2002; Jaroslow et al., 1996; Mei and Kohlstedt, 2000a; Mei and Kohlstedt, 2000b]. In the oceanic mantle water can substantially weaken olivine by enhancing both dislocation and diffusion creep, with a transition occurring at 0.1-1 MPa for a grain size of $10 \mathrm{~mm}$ [Karato et al., 1986]. Dewatering due to mantle melting below mid-ocean ridges may result in the formation of a strong, dry upper mantle layer $\sim 60-70 \mathrm{~km}$ thick, with a viscosity more than an order of mag-

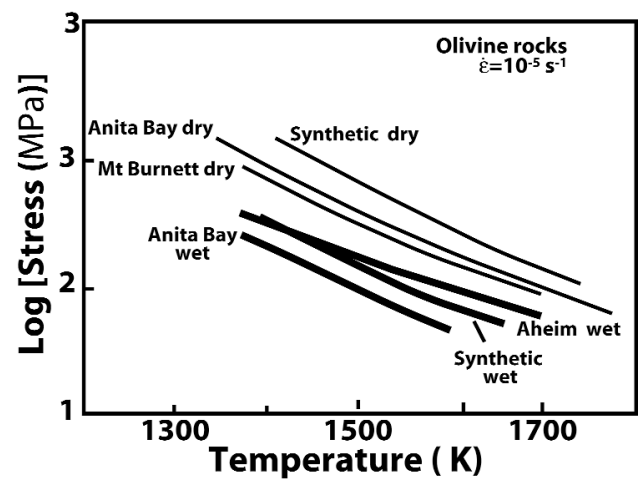

Figure 5. Variations in strength as a function of temperature for olivine with varying amounts of water. "Dry" olivine is stronger than "wet" olivine, but large variability is observed as the actual amount of water is not known. Modified from [Evans and Kohlstedt, 1995]. nitude larger than that of the underlying, wet mantle [Hirth and Kohlstedt, 1996]. A similar water-induced weakening is observed in diabase [Mackwell et al., 1998]. Constraints on the water content of the lithosphere and mantle, and understanding of the processes responsible for hydration and dehydration, are needed in order to apply the experimentally-determined dependence of rheology on water content [Hirth and Kohlst$e d t$, in press]. While the magmatic component of the oceanic crust (i.e., the melt-derived components: gabbro, diabase and basalt) may be nominally dry and therefore strong [Hirth et al., 1998], other processes such as fracturing, water circulation and alteration will result in hydration and eventual weakening.

Grain size is a third parameter than can control the rheology of the lithosphere, and in particular the mode of localization of deformation. In undeformed rocks, grain size largely depends on the cooling history of the rock. However, deformation both during and after cooling also influences grain size [Montesi and Hirth, 2003; Rutter and Brodie, 1988; Van der Wal, 1993]. Studies on naturally deformed abyssal peridotite mylonites show two types of rock recording two conditions and modes of deformation [Jaroslow et al., 1996]: medium to coarse-grained tectonites with equilibrium temperatures $>755^{\circ} \mathrm{C}$, and fine-grained mylonites with equilibrium temperatures of $\sim 600^{\circ} \mathrm{C}$. The first type is interpreted to record deformation associated with mantle upwelling, while the second one may be associated with localized ductile shear zones within the lithosphere that developed during extension and cooling. Grain-size reduction due to dislocation at the base of the lithosphere promoted a transition to the diffusion creep regime (Figure 4), further reducing the strength and favoring strain localization and long-lived faults. These results demonstrate that the mode of deformation and the strength of the lithosphere depend on the evolution of deformation with time, resulting in a complex and variable rheological structure that is not captured by the oversimplified yield strength envelopes commonly used (e.g., Figures 1 and 2).

Finally, the presence of melt can have an important effect on the strength of rocks [Hirth and Kohlstedt, 1995a; Hirth and Kohlstedt, 1995b; Kohlstedt et al., 2000; Renner et al., 2000]. An important strength reduction is documented in the diffusion creep regime at $>5 \%$ melt content, while this reduction occurs at $>4 \%$ melt for rocks deforming in the dislocation creep regime, associated with an increase of one order of magnitude in strain rate (Figure 6).

\subsection{Semibrittle Deformation}

As commonly accepted, all the models presented above are fundamentally oversimplified as they assume that deformation may only occur in either the brittle or the plastic deformation regime (Figure 1). Experimental work in numerous materi- 


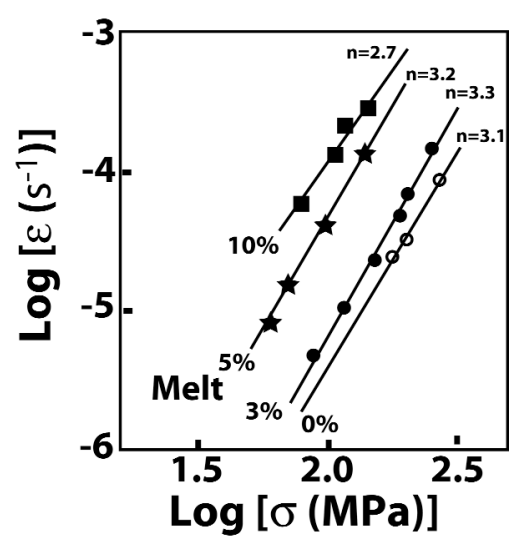

Figure 6. Effect of melt content on olivine rheology. An increase of about an order of magnitude in the strain rate at a constant stress is observed when the melt content increases from 3\% to 5\%. Modified from [Hirth and Kohlstedt, 1995a].

als such as dry clinopyroxene [Kirby and Kronenberg, 1984] or feldspar aggregates [Tullis and Yund, 1992] demonstrate that a more complex behavior occurs in nature. Clinopyroxenites show both plastic and brittle deformation at moderate temperatures $\left(600^{\circ} \mathrm{C}\right)$ and intermediate pressures $(430-1190$ MPa). Feldspars display a cataclastic ductile deformation field with some of the deformation accommodated by plasticity; the onset of deformation occurs at $\mathrm{T}>1000^{\circ} \mathrm{C}$ and $\mathrm{P}>1000 \mathrm{MPa}$ with localized brittle faulting at $\mathrm{T}<300^{\circ} \mathrm{C}$ and $\mathrm{P}<500 \mathrm{MPa}$. Semibrittle behavior can be expected in heterogeneous materials that deform plastically at different pressure and temperature conditions (e.g., olivine, pyroxene and plagioclase in gabbros). This deformation regime is microstructurally complex and has been investigated in a limited number of lithologies. However, constitutive laws for the semibrittle regime are not available, and accurate constraints on the location of the plastic-semibrittle and semibrittle-brittle deformation regimes do not exist, though there are some "rules of thumb." It is commonly accepted that localized brittle deformation occurs when the strength of the rock is larger than that predicted by Byerlee's friction law (Figure 7). Since Byerlee's law does not appear to be universal, this criterion may be improved using the friction law determined for each rock type [Escartin et al., 1997b]. When the strength of the rock is lower than its frictional strength, deformation may be distributed (ductile, semibrittle regime). The onset of fully plastic behavior is assumed to occur when the strength of the rock equals that of the confining pressure (i.e., Goetze's criterion, Figure 7). The definition of the semibrittle regime may be further complicated in the case of heterogeneous materials, such as where brittle and plastic deformation of the different components may coexist under the same conditions [Scholz, 1988]. Incorporating a semibrittle deformation regime into rheolog- ical models results in a profound modification of the yield strength envelope, with significant weakening of both the overall and the peak strength of the lithosphere, compared to 'classical' rheological models (Figure 8).

\subsection{Limitations of Existing Rheological Models}

Commonly used rheological models typically adopt numerous simplifications and assumptions, including the extrapolation of experimental results to natural conditions. For example, note the nine orders of magnitude difference between the experimental strain rates of Figures 5 and 6, and the "geological" rate used in the model of Figure 2. Nevertheless, these models have been successful at predicting and capturing some of the main observations and first-order processes taking place in the lithosphere, such as the brittle behavior of the upper lithosphere and crust and the resulting morphology at the ridge axis [Chen and Morgan, 1990a; Chen and Morgan, 1990b], the nature of faulting and the formation of abyssal hills at the seafloor [Behn et al., 2002b; Macdonald, 1998], or the formation of detachment faults [Lavier et al., 1999].

However, many of the key elements that characterize midocean ridges in general, and slow-spreading ridges in particular, are not captured by current rheological models. In particular, these include: the three-dimensionality of tectonic structures near ridge discontinuities (as existing models are two-dimensional); the heterogeneity in composition of the oceanic lithosphere (mixture of gabbros, peridotite, serpentinite, and other rock types) as opposed to homogenous mod-

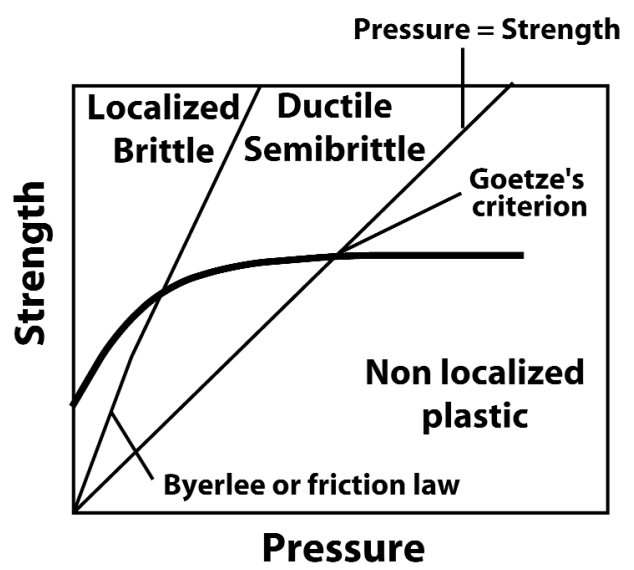

Figure 7. Schematic plot of strength of intact rock versus pressure with criteria to define the deformation regimes. Brittle deformation occurs when the strength of the rock exceeds that of the frictional strength (Byerlee's Law), while plastic deformation is initiated when the strength of the rock equals the pressure (Goetze's Criterion). The region between these two criteria may correspond to the semibrittle regime. After [Evans and Kohlstedt, 1995]. 


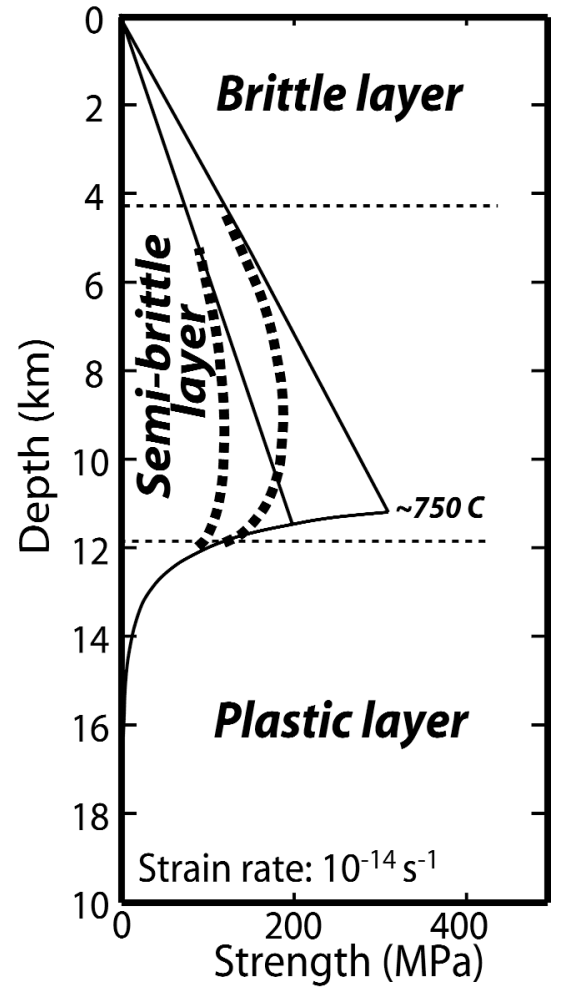

Figure 8. Modified yield strength envelope for a lithosphere exhibiting a field of semibrittle deformation. Both the overall and the peak stress can be significantly reduced compared with the 'classical' rheological model. Two models with differing friction laws (Byerlee's Law and the serpentinite friction law) are shown.

els; and feedback between the different active processes that will in turn affect the rheology of the lithosphere (e.g., hydrothermalism or volcanism, faulting and thermal regime). Some of these aspects, such as the composition of the lithosphere and distribution of lithologies, melt or water, are based on qualitative observations, and require additional high-resolution geophysical constraints to provide quantitative information of use for accurate rheological modeling. Additional experimental work to characterize the rheology of the less abundant lithologies is also required. Even if minor, the presence of a weak phase such as serpentinite or other phyllosilicates can substantially reduce the strength of the lithosphere, and influence the mode of strain localization [Bos et al., 2000; Escartin et al., 1997a]; the effects of these phases are not included in any of the existing mechanical models. Another key rheological parameter that is poorly constrained is temperature. For example, the presence of a magma chamber along portions of fast-spreading ridges, in combination with seismic data, can provide valuable information to construct complex but realistic thermal models under the ridge axis [Dunn et al., 2000]. This information is not widely avail- able, and additional high-resolution three-dimensional studies of lithospheric structure are required, particularly along slow-spreading ridges.

The study of actual deformed rocks offers some insight into and clues on the rheology and processes operating at depth, complementing both geophysical observations and numerical modeling. The comparison of deformed materials in nature and in the laboratory can provide important constraints on the mode of deformation of the lithosphere, and on the T-P conditions at which the rocks and deformation textures were formed. In particular, microstructural observations can be used determine the mode of deformation (brittle vs. plastic and dislocation vs. diffusion creep regimes). This information can be combined with independent constraints on the temperature and pressure (e.g., geothermometry from mineral phase relationships) via the use of deformation mechanism maps such as that shown in Figure 4. Such studies can provide a deep understanding of the thermal state and history of the lithosphere, and of the deformation processes that operate at depth [Jaroslow et al., 1996; Yoshinobu and Hirth, 2002]. These studies are also required to validate the extrapolation of experimental results from laboratory to natural conditions.

Having reviewed these studies of the rheology of ridge materials, we now consider the morphology of ridges, how it is controlled by the rheology, and what further may be learned from it concerning the rheology of the lithosphere.

\section{THE THERMAL STRUCTURE OF OCEANIC LITHOSPHERE}

To a first approximation, the temperature of the oceanic lithosphere can be calculated assuming conductive cooling with a constant mantle temperature at the base of the thermal plate [Parsons and Sclater, 1977]. Implicit in such models is the assumption that the lithosphere is rigid and does not convect on the timescale of thermal conduction. Such models reproduce the general seafloor subsidence with age (depth proportional to the square root of age) for ages $<80 \mathrm{Ma}$. As horizontal heat conduction in the lithosphere is small when compared with the rate of horizontal advection by plate motion, the temperature at depth is mostly a function of age, so slow-spreading ridges display a more rapid increase in lithospheric thickness away from the spreading center than do fast-spreading ridges.

These models break down at ages $>80 \mathrm{Ma}$, as they do not take into account sub-lithospheric convection, which slows plate cooling at large ages [Parsons and McKenzie, 1978; Stein and Stein, 1992]. They also break down in proximity of the ridge axis, as they do not accurately model the thermal effects due to the presence of an axial magma chamber, the latent heat of crystallization, or the advective cooling caused 
by hydrothermal circulation [Chen and Morgan, 1990a; Davis and Lister, 1974; Henstock et al., 1993; Lin and Parmentier, 1989; Phipps-Morgan and Chen, 1993; Wilson et al., 1988]. Current reviews on the thermal state near mid-ocean ridge axes are given by [Sinha and Evans, 2003] and [Chen, 2003].

Critical to the thermal state (and rheological structure) of the lithosphere under the ridge axis is the detailed pattern of hydrothermal circulation and the location and mode of emplacement and extrusion of magma in the crust. Constraints on the axial thermal structure may be more easily obtained and more accurate at fast-spreading ridges than at slow-spreading ones. In addition to a thicker lithosphere, slow-spreading ridges appear to show a heterogeneous crust that implies a non-steady state mode of magmatic accretion [Cannat, 1993; Dick et al., 2000], while the presence of ridge offsets suggests a three-dimensional thermal structure with along-axis variations [Behn et al., 2002a; Shaw, 1992].

Neither the thermal structure nor the details of the hydrothermal cooling process are currently well constrained because of difficulties in sampling appropriate parts of the oceanic crust, or in geophysically imaging these areas or the effects of the processes. Geological constraints on the extent, depth, mode and temperature conditions of hydrothermal alteration are beginning to be obtained from ophiolites, e.g., [Gillis and Roberts, 1999]. [Phipps-Morgan and Chen, 1993] have modeled the general effect of hydrothermalism and show that the yield strength of the lithosphere and its effective elastic thickness depend on the balance between the rate of heat input by magma injection into the crust and the rate of hydrothermal cooling.

Two broad models exist for magma emplacement into the lower crust at fast-spreading ridges (Figure 9). In the "gabbro glacier" model, emplacement of magma takes place in a shallow sill-like magma chamber at the base of the sheeted dyke layer (corresponding to the seismically imaged axial magma chamber at fast-spreading ridges). Subsequent freezing and down- and outward movement of the crystallized residue constructs the lower crust [Henstock et al., 1993; Phipps-Morgan and Chen, 1993; Quick and Delinger, 1993]. The more recent "multiple sill" model proposes magma injection in multiple lenses throughout the crustal section including near the Moho [Crawford and Webb, 2002; Kelemen and Aharonov, 1998; MacLeod and Yaouancq, 2000]. At present neither model appears to completely satisfy all the available geological and geophysical evidence.

Efforts are underway to better constrain the thermal state below the ridge axis by studying oceanic samples that record the interaction of hydrothermal fluids with the host rock, thus providing constraints on the thermal conditions at which such interaction occurred [Coogan et al., 2002; Manning and

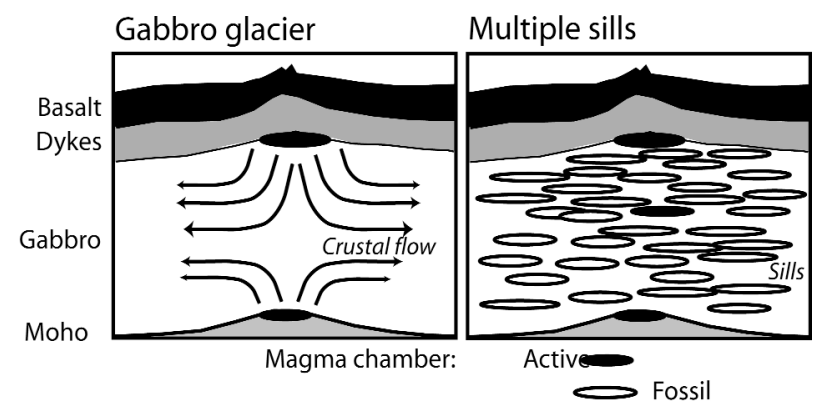

Figure 9. Models of crustal formation for a fast-spreading ridge. (Left) In the 'gabbro glacier' model most of the lower crust is produced from a high-level magma sill at the base of the dyke section by solid flow of the melt residue down and off-axis [Henstock et al., 1993; Phipps Morgan and Chen, 1993; Quick and Delinger, 1993]. A similar process may operate from a magma chamber at the base of the crust. (Right) In the 'many sills' model the crust is formed by emplacement of thin melt lenses into the crust at different levels between the Moho and a high-level magma chamber [Crawford and Webb, 2002; Kelemen and Aharonov, 1998]. These magma chambers may be emplaced independently [Kelemen et al., 2000], or as lateral extensions from a magmatic system feeding a high-level magma chamber from the upper mantle [MacLeod and Yaouancq, 2000].

MacLeod, 1996; Manning et al., 2000], and from cooling rates inferred from grain sizes in ophiolites [Garrido et al., 2001].

\section{FLEXURE AND THE ELASTIC PROPERTIES OF THE LITHOSPHERE}

Various authors have estimated the effective elastic thickness of the lithosphere by measuring its flexural deformation under loads such as seamounts, islands, ridges, fracture zones and trenches [Caldwell et al., 1976; Cazenave et al., 1980; Watts, 1978]. [Goetze and Evans, 1979] used experimental rock mechanical data to construct strength yield envelopes (see Figure 1) which could be used to study the elastic properties and bending of the lithosphere. This approach has been extensively used to obtain rheological information from flexural studies [Kirby, 1983; McNutt and Menard, 1982]. Recent compilations of results from numerous flexural studies are given by [Watts and Zhong, 2000] and [Minshull and Charvis, 2001] (Figure 10). These studies treat the lithosphere as a thin elastic plate overlying an inviscid substratum, and infer the flexural rigidity D from the shape of the deformed plate and the estimated load. The effective elastic thickness $T_{e}$ is related to $D$ :

$$
\mathrm{D}=\mathrm{ET}_{e}^{3} / 12\left(1-\mathrm{v}^{2}\right)
$$

where E is Young's modulus and $v$ is Poisson's ratio. 


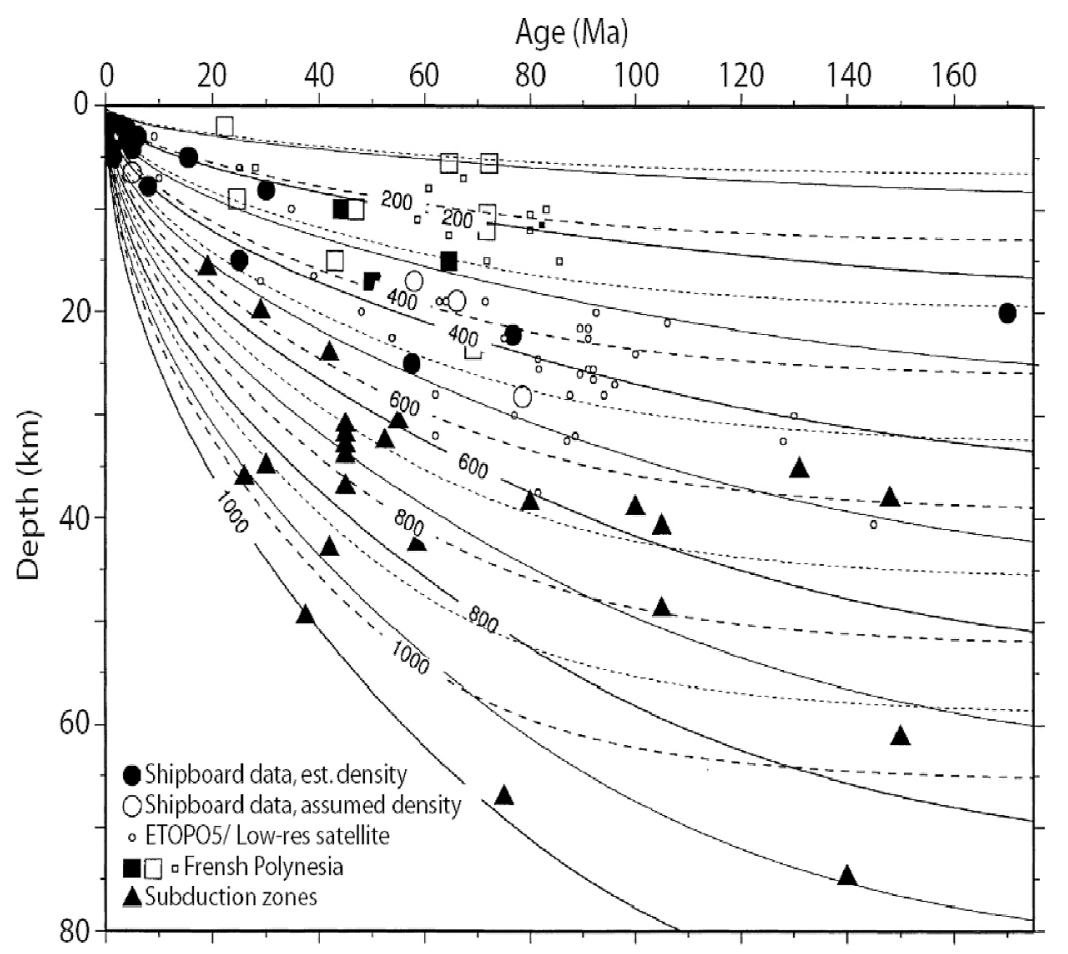

Figure 10. Comparison of the temperature structure of an oceanic plate with estimates of elastic thickness of the lithosphere from flexural studies (adapted from [Minshull and Charvis, 2001]; see also references therein). The thermal models are those of [Parsons and Sclater, 1977] (solid lines) and [Stein and Stein, 1992] (dashed lines). Many of the flexural estimates give significantly lower values for lithospheric thickness than those that may be predicted by the thermal models.

In these studies, the envelope of all results shows an overall increase in the effective elastic thickness with age at time of loading, with most data bounded by the $\sim 600^{\circ} \mathrm{C}$ isotherm (see Figure 10). This temperature is close to the predicted temperature corresponding to the brittle to plastic transition in classical rheological models (Figure 1). Many measurements, however, give elastic plate thickness estimates that are much smaller than the elastic thickness predicted by this isotherm (Figure 10).

Elastic thickness values reported for zero-age oceanic crust range from 0 to $>10 \mathrm{~km}$ [Bowin and Milligan, 1985; Cochran, 1979; Escartin and Lin, 1998; Kuo et al., 1986; Madsen et al., 1984; McKenzie and Bowin, 1976; Neumann et al., 1993; Wang and Cochran, 1993] . Estimates of the effective elastic thickness for the East Pacific Rise tend to be less than $4 \mathrm{~km}$, while those for the Mid-Atlantic ridge range from less than 5 $\mathrm{km}$ to more than $10 \mathrm{~km}$, consistent with a slightly thicker lithosphere under slow-spreading ridge axes. A value of $4 \mathrm{~km}$ is reported for the intermediate-spreading Juan de Fuca Ridge [Watts and Zhong, 2000]. However, estimates of elastic thickness at slow-spreading ridges may be biased by tectonic modification of both the thickness and seafloor morphology due to tectonic extension along the bounding rift faults [Escartin and Lin, 1998].
Lithospheric thickness may also be estimated seismically, e.g., by modeling surface-wave dispersion. Such methods yield lithospheric thickness estimates that are larger than those from flexural studies, fitting closer to the $1000^{\circ} \mathrm{C}$ isotherm [Leeds et al., 1974; Nishimura and Forsyth, 1989]. These discrepancies may be explained by the differences in the strain-rates involved: lithospheric flexure reflects deformation on the timescale of millions of years, while passage of seismic waves occurs on a time scale of seconds, emphasizing the strain-rate dependence of lithospheric rheology (see Figures 1 and 4).

\section{THE THICKNESS OF THE SEISMOGENIC ZONE}

Oceanic intraplate earthquakes occur over a broad range of depths, but a well-defined maximum depth is identifiable and increases with lithospheric age [Wiens and Stein, 1983] (Figure 11). This limit corresponds approximately to the $750^{\circ} \mathrm{C}$ isotherm, somewhat deeper in the Earth and at a higher temperature than that derived from flexural studies, but in agreement with the temperature of the brittle to plastic transition [Bergman and Solomon, 1990; Chen and Morgan, 1990a]. [Wiens and Stein, 1983] estimated seismogenic strain rates 


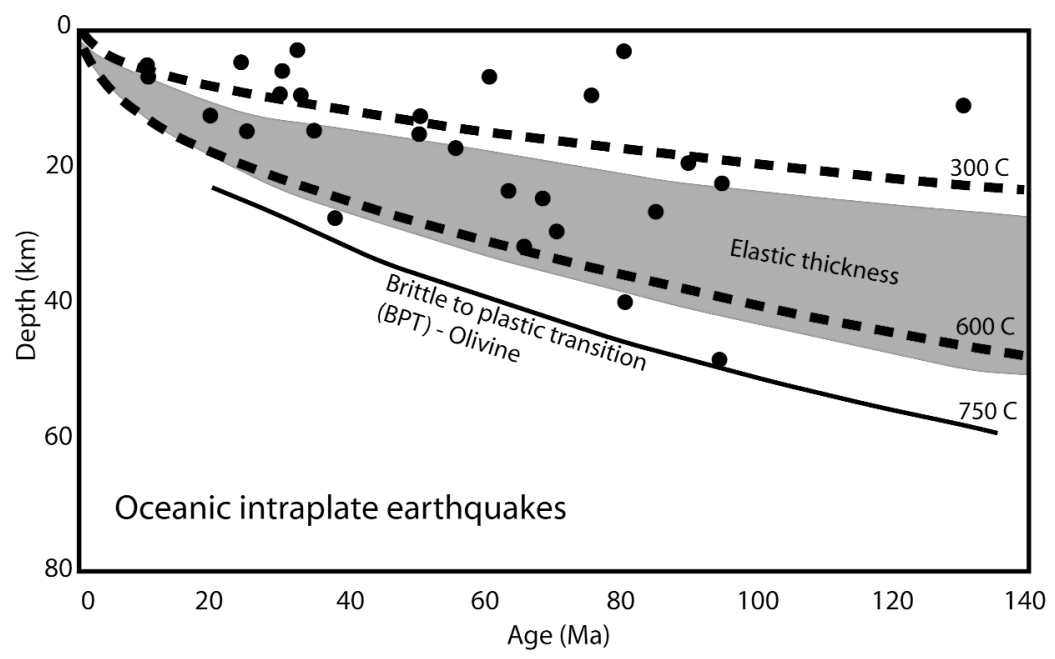

Figure 11. Oceanic intraplate earthquake depths as a function of lithospheric age. The dashed lines correspond to the $300^{\circ} \mathrm{C}$ and $600^{\circ} \mathrm{C}$ isotherms, and the brittle to plastic transition for olivine is indicated by the continuous line $\left(\sim 750^{\circ} \mathrm{C}\right)$. After [Wiens and Stein, 1983].

from seismic moment release rates, concluding that they lie in the range of $10^{-18}$ to $10^{-15} \mathrm{~s}^{-1}$ for normal and highly active tectonic lithosphere, respectively. Assuming a dry olivine rheology and using values for the constants in the flow-law equations derived from laboratory rock mechanics experiments, they found that the maximum deviatoric stress that can be supported at $750^{\circ} \mathrm{C}$ is $20 \mathrm{MPa}$ and $190 \mathrm{MPa}$ at the lowest and highest strain rates, respectively. The critical depths at which these stresses are exceeded differ by only $5-10 \mathrm{~km}$ for these two strain rates.

A number of studies have estimated the depth of the seismogenic zone at mid-ocean ridges. Centroid depths of teleseismic events [Huang and Solomon, 1988] show a deepening with decreasing spreading rate, from less than $2 \mathrm{~km}$ depth at rates of $>20 \mathrm{~km} \mathrm{Ma}-1$ to $\sim 6$ for $<5 \mathrm{~km} \mathrm{Ma}^{-1}$ (Figure 12). A more detailed view of the distribution of seismicity is available from microseismicity studies using ocean-bottom seismometers that have been conducted on a limited number of mid-ocean ridge sites. Maximum hypocentral depths for the very slow-spreading South West Indian Ridge range from 6 to $10 \mathrm{~km}$ [Katsumata et al., 2001]. Studies along the Mid-Atlantic ridge show a large variation in maximum hypocentral depth, both regionally and locally, ranging from $<4 \mathrm{~km}$ to $>10 \mathrm{~km}$ below seafloor, so that the deeper events occur within the upper mantle [Barclay et al., 2001; Kong et al., 1992; Louden et al., 1986; Tolstoy et al., 2002; Toomey et al., 1988; Toomey et al., 1985; Wilcock et al., 1990; Wolfe et al., 1995]. Some slow-spreading segments show seismicity limited to shallow levels, with maximum depths of $\sim 4 \mathrm{~km}$ (e.g., OH1 segment [Barclay et al., 2001]). This shallow limit on the seismicity was originally attributed to the commonly assumed weak nature of the lower crust, although recent work suggests that the lower crust is strong [Hirth et al., 1998] so this shallow seismicity most likely reflects a thin lithosphere at this location. Other slow-spreading segments, such as the $29^{\circ} \mathrm{N}$ area of the MidAtlantic Ridge, show hypocenter depths that vary from $<6$ $\mathrm{km}$ at the segment center to $>9 \mathrm{~km}$ under the inside corner at the segment end [Wolfe et al., 1995], thus reaching into the upper mantle (Figure 13). In most cases the seismicity tends to cluster near these maximum depths, with a zone of lesser activity in the upper crust and a relatively aseismic zone in between. Maximum hypocentral depths at medium and fastspreading ridges tend to be smaller. They are on the order of $1.5-3.5 \mathrm{~km}$ at the Juan de Fuca Ridge [Wilcock et al., 2002], $3-5 \mathrm{~km}$ at the fast-spreading East Pacific Rise near transform faults [Lilwall et al., 1981], and $<3 \mathrm{~km}$ away from transforms [Tolstoy et al., 2002]. Variations in the maximum hypocentral depths therefore reflect the overall trends in elastic thickness inferred from flexural studies.

In the next sections we review some of the main observations regarding rift valley morphology, crustal thickness variations, and lithospheric composition as constrained from geophysical and geological investigations. These data are critical for constraining the composition of the lithosphere and the geometry of its different components, which in turn are required to construct more realistic and better constrained rheological models.

\section{THE MEDIAN VALLEY AND THE AXIAL HIGH}

An important characteristic of slow-spreading mid-ocean ridges is the median valley (Plate 1). Along many sections of 


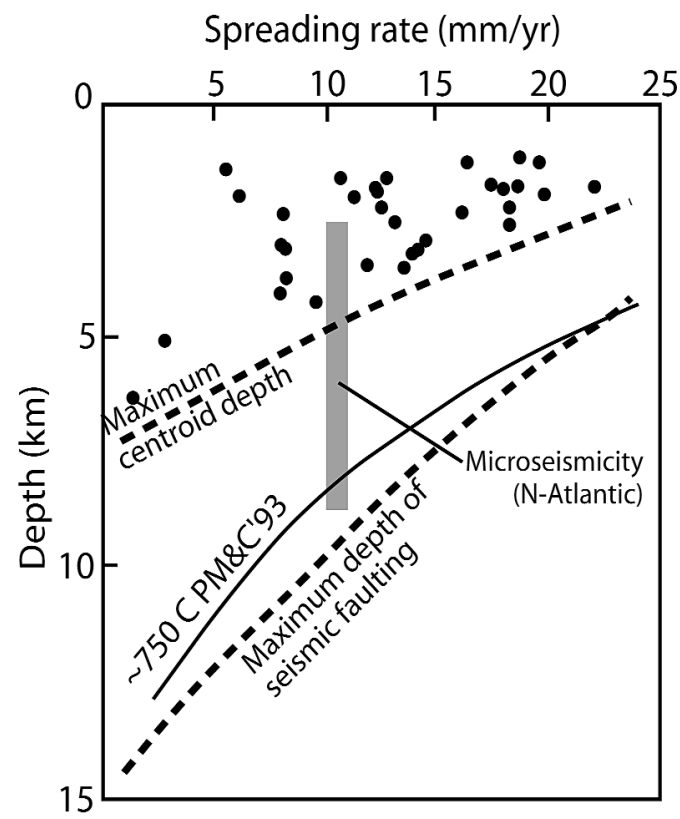

Figure 12. Plot of centroid depth versus half spreading rate for midocean ridge axis earthquakes [Huang and Solomon, 1988]. As the centroid depth corresponds to the weighted centre of the focal volume, the inferred maximum depth of faulting is double this. These data are in agreement with the distribution of microseismicity along the northern Mid-Atlantic Ridge (grey box; see [Barclay et al., 2001] and references therein). The solid line (PM\&C'93) corresponds to the $750^{\circ} \mathrm{C}$ isotherm in the thermal models of [Phipps Morgan and Chen, 1993].

slow-spreading ridges there is an axial rift, several kilometers wide and 1-3 km deep, which is produced by stretching and necking of the lithosphere under horizontal tension as plates separate [Chen and Morgan, 1990a; Lin and Parmentier, 1989; Tapponnier and Francheteau, 1978]. At fast-spreading ridges the median valley disappears and is replaced by an axial high, which reflects dynamic viscous support and flexural bending of a thin plate over a hot axial region [Buck, 2001; Chen and Morgan, 1990b; Eberle and Forsyth, 1998; Madsen et al., 1984; Wang and Cochran, 1993]. Transitional morphologies are found at intermediate-spreading ridges, and other effects, such as the presence of hotspots, also play a role on ridge morphology, e.g., [Canales et al., 1997; Searle et al., 1998b].

Such a morphological transition is shown by simple rheological models that assume a brittle layer overlying power-law creep rheology, passive mantle upwelling driven by plate separation, and incorporating the effects of both hydrothermal cooling and the latent heat of crystallization [Chen and Morgan, 1990a; Chen and Morgan, 1990b]. Rift valley morphology is therefore a general indicator of the mechanical properties and overall thermal state of the lithosphere under the ridge axis. These early rheological models assumed a weak lower crust deforming plastically and decoupled from the stronger upper mantle [Chen and Morgan, 1990a; Shaw and Lin, 1996]. This plastically deformed zone was thought to be associated with the aseismic zone often observed in microseismicity studies (Figure 13). The decoupling zone in these models is narrow at slow-spreading ridges: in the highstress axial zone, the brittle upper crust exceeds its strength, fails, and is subsequently deformed plastically by the diverging ductile mantle (necking) to produce the rift valley. At faster spreading rates the axial region is hotter so the decoupling zone (ductile lower crust) is wider and exceeds the width of the zone of brittle failure. The thin and very weak axial lithosphere is thus decoupled from the mantle flow and, in these models, achieves almost perfect local isostatic equilibrium, producing an axial high, since there is little dynamic support for the topography.

The behavior of the [Chen and Morgan, 1990a] model depends critically on the crustal thickness. A thinner crust may reduce or totally remove the lower crustal decoupling zone, and the model then predicts a wider and deeper rift valley; this model has been invoked to explain the presence of an axial valley along the Australia-Antarctic Discordance [Chen and Morgan, 1990a; Hirth et al., 1998], where the mantle is inferred to be cold and to have a very low degree of melting [Weissel and Hayes, 1974]. By contrast, hotter mantle results in thicker crust, as observed near hotspots (e.g., Reykjanes Ridge [Bunch and Kennett, 1980]); the decoupling zone is then wider than the failure zone, and the lithosphere behaves like the fast-spreading case, producing an axial high [Chen and Morgan, 1990b]. This model was adopted and developed by [Neumann and Forsyth, 1993] and [Shaw and Lin, 1996] to

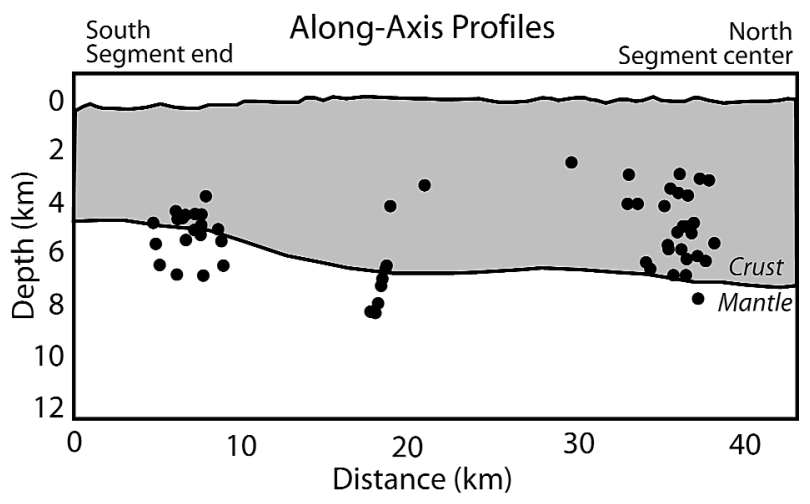

Figure 13. Distribution of microseismicity along the axis of a slowspreading ridge segment (Mid-Atlantic Ridge, $29^{\circ} \mathrm{N}$; see Plate 1 for location) over a 42 day period. Microseismicity clusters in three areas, at depths from $2 \mathrm{~km}$ to $9 \mathrm{~km}$, mostly in the lower crust and upper mantle. Note that the mid-crust is relatively aseismic at depths $\sim 5 \mathrm{~km}$. After [Wolfe et al., 1995]. 


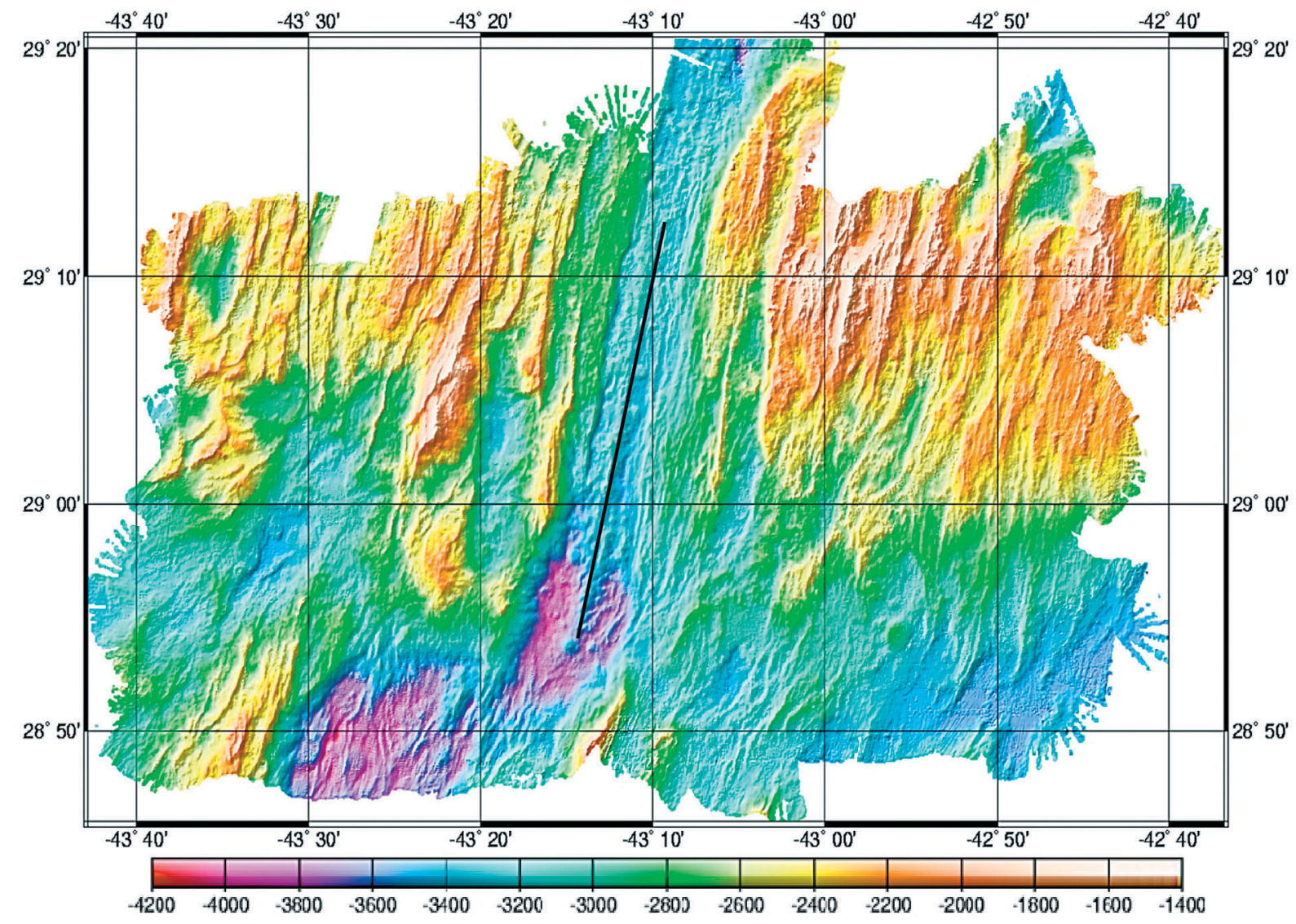

Plate 1. Shaded relief bathymetry over the southernmost two thirds of the $29^{\circ} \mathrm{N}$ segment of the Mid-Atlantic Ridge, illuminated from the northwest [Searle et al., 1998a] and unpublished data]. Note the well-defined fault scarps facing towards the ridge axis, which outline both the median valley floor (centered at $29^{\circ} 02^{\prime} \mathrm{N}, 43^{\circ} 10^{\prime} \mathrm{W}$ ), and the $>1.5 \mathrm{~km}$ scarp at $28^{\circ} 55^{\prime} \mathrm{N}, 43^{\circ} 18^{\prime} \mathrm{W}$ that defines the inside corner high centered near $29^{\circ} \mathrm{N}$ and $43^{\circ} 20^{\prime} \mathrm{W}$. The line corresponds to the axial section showing the microseismicity in Figure 13. 
explain variations in seafloor morphology and faulting as a response to variations in the rheological structure along the ridge axis.

Recently this 'weak crust' model has been questioned on the basis of new experimental rheological data and geological arguments [Hirth et al., 1998; Hirth and Kohlstedt, in press]. Recent experimental work on the rheology of dry diabase shows that this rock, at geologically relevant conditions, is much stronger than the wet 'diabase' reported in earlier experimental work, and has a similar strength to that of olivine [Mackwell et al., 1998]. As water is a highly incompatible element in the mantle and present in small quantities, it is partitioned into the melt. As a consequence, both the mantle, having undergone a small amount of melting [Hirth and Kohlstedt, 1996], and the lower crust, formed by cumulate gabbros from which the melt (and hence the water) has been extracted, are nominally dry. Therefore, rheological models of the lower crust should adopt a 'dry' diabase rheology instead of the 'wet' one commonly used. Later hydration of the crust can occur due to circulation of fluids in the lithosphere, but this process requires the presence of fractures and interconnected porosity that is only possible in the brittle regime. This hydration will have consequences for the rheology of the brittle lithosphere (e.g., serpentinisation [Escartin et al., 1997a]), but it is unlikely to affect the plastic, impermeable levels of the lithosphere. [Hirth and Kohlstedt, in press] suggest that in fact weak lower crust is less critical to these models than suggested by [Chen and Morgan, 1990a], and that increasing temperature may be the dominant effect rather than a weak lithology. Moreover, the isostatic balance of the axial high has also been questioned, and more recent work suggests that the high is regionally supported by dynamic viscous flow [Eberle and Forsyth, 1998] or by stresses in the brittle lithosphere [Buck, 2001].

The presence of a continuous magma chamber at fastspreading ridges [Babcock et al., 1998; Vera et al., 1990] and its absence at slow-spreading ridges [Detrick et al., 1990; Lin et al., 2003] demonstrates that the rheological structure of fast and slow-spreading ridges are fundamentally different [Poliakov and Buck, 1998]. A magma lens at shallow crustal levels necessarily implies that the brittle layer above it is very thin and can be easily faulted or dissected by dykes. In contrast, the emplacement of discrete and ephemeral magma chambers in the thick lithosphere of slow-spreading ridges will result in large temporal variations in the rheological structure of the ridge axis. Over long periods of time, the thickness of the lithosphere at slow-spreading ridges can thus be assumed to be large and to vary gradually along the length of ridge segments, as indicated by the gradual variation in rift valley width and depth along axis. A thin lithosphere may be expected immediately after the emplacement of a magma chamber, but such events must be limited both spatially and temporarily so as to maintain the axial rift valley.

\section{MORPHOLOGY AND CRUSTAL ARCHITECTURE OF RIDGE SEGMENTS}

The use of swath bathymetry, gravity and seismic studies along segmented slow-spreading ridges such as the MidAtlantic Ridge have revealed systematic along-axis variations from the segment ends to the segment center [Detrick et al., 1995; Hooft et al., 2000; Hosford et al., 2001; Kuo and Forsyth, 1988; Lin et al., 1990; Magde et al., 2000; Purdy et al., 1990; Searle et al., 1998a; Sempéré et al., 1995; Thibaud et al., 1998] (Plate 1). Segments tend to be shallower and have a thicker crust at the segment center, which is considered to be an indication of focused magmatic accretion at the midpoint [Lin et al., 1990; Magde et al., 1997; Tolstoy et al., 1993]. Crustal thickness variations along a segment can be as large as $7 \mathrm{~km}$, with thicknesses of $<3 \mathrm{~km}$ at the segment end increasing to $>9 \mathrm{~km}$ at the center, e.g., [Hooft et al., 2000]. Seismic data also show that the thickness variations occur primarily in layer $3\left(\mathrm{~V}_{\mathrm{p}} \sim 6.8-7.2 \mathrm{~km} / \mathrm{s}\right)$, while the thickness of layer 2 remains relatively constant (Figure 14). Ultra slowspreading ridges such as the South West Indian Ridge show a more extreme focusing of melt, with the construction of large central volcanoes at the centers of some segments while others are relatively magmatically starved [Cannat et al., 1999; Dick et al., 2003; Fujimoto et al., 1999; Michael et al., 2003]. Segments have a typical length of 40-90 km [Schouten et al., 1985] and are generally sub-perpendicular to the direction of relative plate separation, although highly oblique segments are found near hotspots [Abelson and Agnon, 1997; Searle et al., 1998b] and in extended regions of oblique spreading [Taylor et al., 1994].
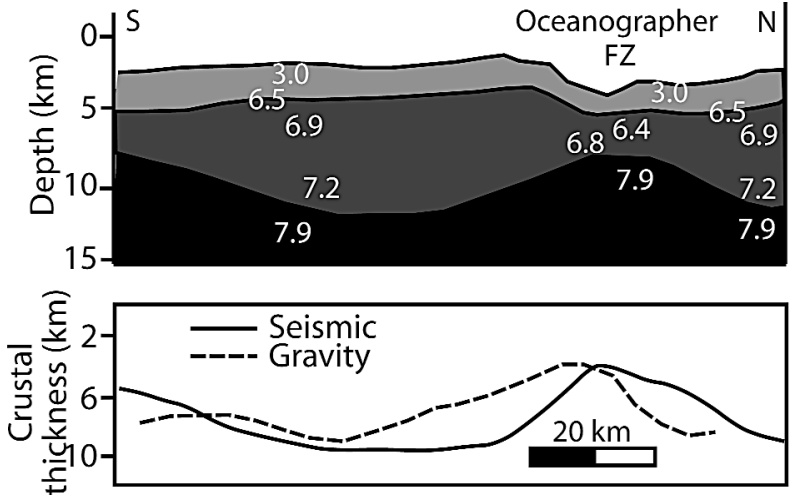

Figure 14. Along-axis variation of crustal thickness based on seismic observations (top) and gravity modeling (bottom). Note that the direction of the gravity scale is reversed. After [Detrick et al., 1995]. 
Segments are laterally offset from each other by up to $30 \mathrm{~km}$ in "non-transform discontinuities" (NTDs), or by transform faults that normally accommodate larger offsets [Fox et al., 1991; Grindlay et al., 1991; Grindlay et al., 1992]. NTDs leave wakes of depressed seafloor that show along-axis migration rates comparable to the spreading rate or higher [Kleinrock et al., 1997], and that can lead to the lengthening and shortening of segments, and to their nucleation or extinction [Gente et al., 1995; Rabain et al., 2001; Tucholke et al., 1997]. NTD migration along axis may be driven by changes in plate motion, differential variations in the relative magma supply or thermal state of adjacent segments [Phipps Morgan and Sandwell, 1994; West et al., 1999]. In some cases "magmatically robust" segments, characterized by a shallow axis and narrower axial valley at the segment center, and showing evidence of voluminous volcanism, tend to grow at the expense of adjacent segments by the migration of the NTDs away from the segment center [Gente et al., 1995; Rabain et al., 2001; Thibaud et al., 1998]. NTD migrations can also be driven by pressure gradients induced by topographic gradients across discontinuities [Phipps Morgan and Parmentier, 1985].

In the longer term, asymmetric spreading between adjacent spreading segments can vary the ridge offset, and promote a change from an NTD to a rigid, non-migrating transform fault or vice versa [Grindlay et al., 1991]. The actual mechanism of NTD propagation is poorly understood, but requires the alongaxis propagation of dykes and extensional faults into the crust formed at the adjacent segment across the segment boundary. Large offsets $(>\sim 30 \mathrm{~km})$ will result in a thicker, cooler and therefore stronger lithosphere across a discontinuity, thus arresting the propagation of dykes and faults across it.

Similar plate-boundary segmentation is observed at both intermediate and fast-spreading ridges, but without the major morphological and crustal thickness changes observed at slow-spreading ridges. Crustal thickness variations along fastspreading ridges and away from major transform offsets are of a much smaller amplitude (typically $<2 \mathrm{~km}$ ) than those observed at slow-spreading ridges [Bazin et al., 1998; Canales et al., 1998; Madsen et al., 1990]. The detailed morphology of the axial volcanic ridge does not directly correlate with the presence of a magma chamber, as some, but not all, discontinuities appear to be underlain by well-developed melt lenses [Bazin et al., 2001; Kent et al., 2000]. The presence of a melt lens above a zone of hot crust, possibly containing small amounts of melt, probably results in a weak crust that can deform plastically to accommodate variations in morphology and structure associated with ridge segmentation at the surface [Bell and Buck, 1992].

Slow-spreading ridges have characteristic tectonic patterns that demonstrate that both the seafloor morphology and the crust formed at the ridge axis undergo significant modifica- tion at the rift bounding walls [Escartin and Lin, 1998] (see Figures 14, 16). Along the ridge axis, the shallowest point in the rift valley and the thickest crust are located at the segment center, and the thinnest crust is found below the ridge discontinuities. Outside the rift valley, the shallowest points are commonly located in close proximity to the segment ends, at the inside corners of the ridge-transform or ridge-NTD intersections, while the thinnest crust is found under the elevated inside corners, where the topography must be dynamically supported [Escartin and Lin, 1995; Rommevaux-Justin et al., 1997; Tucholke et al., 1997]. The outside corners are commonly more subdued topographically and tectonically, indicating asymmetric tectonic processes and uplift [Severinghaus and Macdonald, 1988].

Ridge segmentation is generally agreed to be intimately associated with the pattern of melt delivery at mid-ocean ridges, although the ultimate cause of segmentation remains uncertain. While some models have suggested that segmentation may be controlled by focused mantle upwelling or mantle diapirs [Lin and Phipps Morgan, 1992; Lin et al., 1990; Whitehead et al., 1984], numerical modeling suggests that, for realistic viscosities, the characteristic size of diapirs exceeds the characteristic length of slow-spreading ridge segments [Barnouin-Jha et al., 1997; Sparks and Parmentier, 1993]. Segmentation is more likely controlled by brittle processes in the lithosphere [Macdonald et al., 1991b; Macdonald et al., 1986; Pollard and Aydin, 1984], with some interaction and feedback with magmatic processes (e.g., focusing of melt to the center of segments at slow-spreading ridges). This feedback is supported by the apparent constant average melt supply from the mantle to three adjacent segments of different length along the Mid-Atlantic Ridge that otherwise display important differences in the absolute variations in crustal thickness along individual segments [Hooft et al., 2000]. Initial melt focusing at the segment center can be achieved by melt migration along axis at the base of the lithosphere (following shallowly dipping isotherms), or by focusing within the lithosphere itself [Magde and Sparks, 1997; Magde et al., 1997; Sparks and Parmentier, 1993]. The thinner crust at the ends of slow-spreading ridge segments results from along-axis dyke propagation from the segment center [Hooft et al., 2000; Lawson et al., 1996]. This crustal structure formed at the ridge axis, as mentioned above, is later modified [Canales et al., 2000b; Hosford et al., 2001] by extensional faulting along the rift valley walls [Escartin and Lin, 1998] as the crust is rifted off axis. The asymmetry in crustal thickness between inside and outside corners may result from initial asymmetric crustal accretion [Allerton et al., 2000], possibly followed by asymmetric tectonic thinning [Escartin and Lin, 1998]. A summary of these processes is shown in Figure 15. 


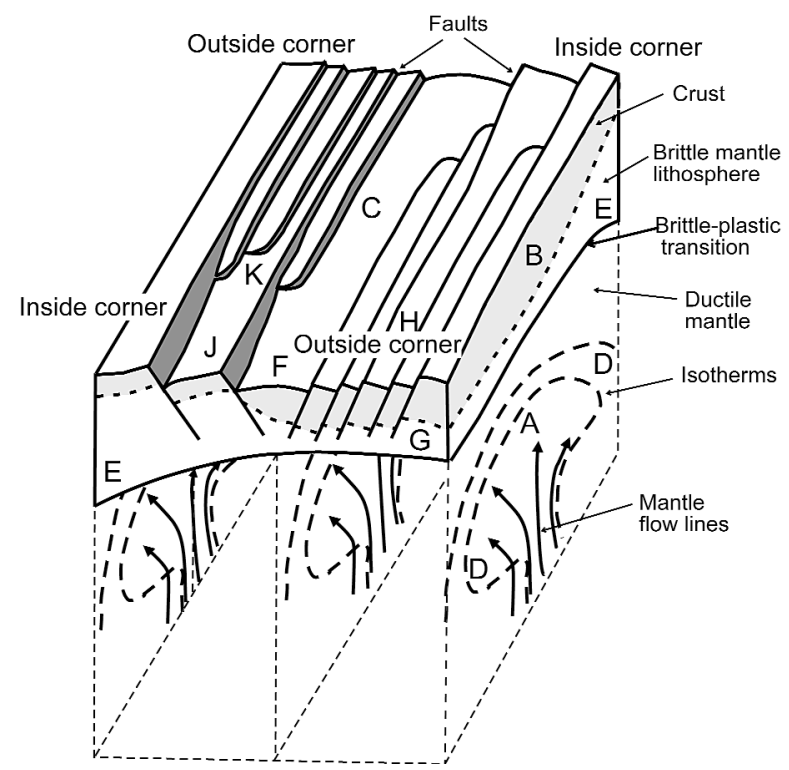

Figure 15. Block model of varying fault style along a slow-spreading ridge segment, modified from [Shaw, 1992; Shaw and Lin, 1993]. Crust is indicated by light grey shading, but the crust-mantle boundary is dashed to emphasise that it is unlikely to be a simple layered structure, but comprises a mixture of melt-derived rock (gabbro, diabase and basalt) and peridotite (see also Figure 16). Mantle wells up strongly under the segment centre (A), producing a high thermal gradient, enhanced melting and therefore thin lithosphere but thick crust (B). These conditions yield a weak lithosphere that deforms by closely-spaced, relatively low-amplitude faulting (C). Weaker mantle upwelling at segment ends (D) leads to lower thermal gradient, less melting, and therefore a thicker lithosphere and thinner crust (E). However, asymmetric crustal accretion at the segment end (F) leads to thicker crust under the outside corner [Allerton et al., 2000], which weakens the thermally thicker lithosphere there so that the BPT is shallower $(\mathrm{G})$ than under the inside corner (E). Consequently the faulting style at the outside corner $(\mathrm{H})$ is similar to that at the segment centre $(\mathrm{C})$ [Escartin et al., 1999], while the stronger lithosphere at the inside corner can support much larger but more widely spaced faults $(\mathrm{J})$. The different fault styles are accommodated by across-axis linking of faults ([Searle et al., 1998a], K). It is likely that the growth of large faults at the inside corner is also facilitated by weakening of the fault through serpentinisation [Escartin et al., 1997a].

\section{LITHOLOGICAL STRUCTURE OF MID-OCEAN RIDGES}

Geological observations and sampling of both fast- and slow-spreading ridges demonstrate that these have fundamental differences in the composition and architecture of the crust below the ridge axis and the mode of magmatic accretion. Sampling of normal oceanic crust formed along fastspreading ridges yields basaltic rocks extruded at the seafloor (upper seismic Layer 2). Lithologies that have been emplaced within lithosphere at deeper levels, such as diabase, gabbros (lower seismic layer 2 and layer 3 of the crust) and peridotite (mantle) are only found along transform faults or rift zones [Früh-Green et al., 1996; Karson, 1998; Karson et al., 2002; MacLeod and Manning, 1996; Mével and Stamoudi, 1996]. In these areas the pre-existing oceanic crust has been rifted and sections of the crust and deeper lithospheric levels exposed to the seafloor. Ocean drilling at site ODP 504B [Shipboard Scientific Party, 1993; Shipboard Scientific Party, 1995] , corresponding to intermediate-spreading crust, has revealed a $600 \mathrm{~m}$ thick layer of extrusive basalts, underlain by an $\sim 200$ $\mathrm{m}$ thick transitional zone in turn underlain by at least $1 \mathrm{~km}$ of sheeted dykes. Correlations of physical properties (e.g., seismic velocity) and recovered lithologies demonstrate that seismic velocity reflects variations in porosity rather than composition, as often assumed [Detrick et al., 1994].

Sampling of slow-spreading ridges demonstrates that the simple layered structure is not correct for these ridges [Cannat, 1993; Cannat, 1996]. Here, outcrop of gabbro and peridotite (mostly serpentinized) at the seafloor is relatively common, and was recognized early on [Aumento and Loubat, 1971; Auzende et al., 1989; Bonatti and Hamlyn, 1978; Bonatti and Harrison, 1976; Dick, 1989; Engel and Fischer, 1953; Hekinian, 1968; Juteau et al., 1990; Melson et al., 1966; Prinz et al., 1976]. These "deeper" rocks are most commonly found at the ends of slow-spreading segments and at inside corners, where the geophysically defined crust is thinner, and where tectonic processes appear to be more effective in exposing deeper lithologies. Tectonic models have been put forward in which the crust is extremely thin or altogether absent from inside corners (Figure 16), and deep lithologies are exposed along large-offset faults [Blackman et al., 1998; Cann et al., 1997; Cannat, 1993; Cannat, 1996; Dick et al., 1991; Karson, 1998; Karson and Lawrence, 1997; Kurewitz and Karson, 1997; Tucholke and Lin, 1994].

Peridotite outcrops are not restricted to the ends of segments or ridge discontinuities, but may also found along the centers of some segments [Cannat, 1993; Cannat and Casey, 1995; Cannat et al., 1997; Cannat et al., 1995; Dick, 1989; Lagabrielle et al., 1998]. While it is thought that these segmentcenter peridotites may be more common at ultra-slow-spreading rates or ridges overlying unusually cold mantle, they are not restricted to such cases, and the precise conditions for their occurrence are not yet understood. These peridotite outcrops extend over several kilometers along the ridge axis, and are often capped by a thin layer of extrusive basalts. Although often referred to as "amagmatic", such crust may actually contain $\sim 25 \%$ gabbro intruded into the peridotite [Shipboard Scientific Party, 2003]. Sections of ultra slow-spreading centers, such as the Gakkel ridge and South West Indian Ridge, 


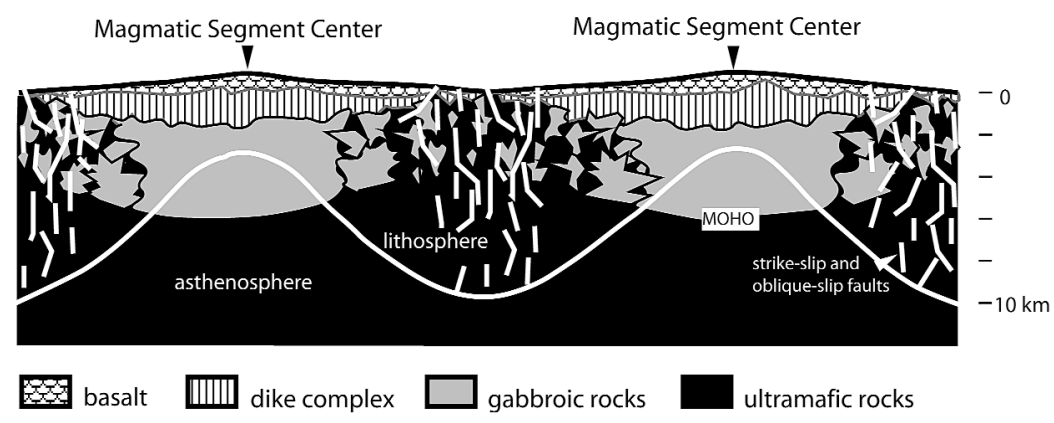

Figure 16. Along-axis variation in crustal thickness and lithology after [Cannat et al., 1995]. Continuous white line represents the base of the lithosphere, approximately following an isotherm. White, sub-vertical lines represent mantle dykes. Note variations in crustal thickness and discontinuous nature of lower crust (gabbroic layer) at segment ends.

in addition to a geophysically thin crust, display ridge sections that correspond to tectonic stretching of the mantle lithosphere with little or no magmatism [Coakley and Cochran, 1998; Cochran et al., 2003; Dick et al., 2003; Jokat et al., 2003; Lin et al., 2003; Michael et al., 2003].

These geological observations are inconsistent with a layered crustal model, as in most cases the fault scarps do not have sufficient throw to expose lower crustal and upper mantle levels. Instead, the geological constraints indicate that the crust can be compositionally heterogeneous [Cannat, 1993; Cannat, 1996; Cannat et al., 1995], that transitions from a "magmatic" to a discontinuous or absent crust can occur along individual segments, and that the process of magmatic accretion is not continuous. Instead, magma is emplaced in discrete bodies in the thick, cold lithosphere, feeding the axial volcanism (Figure 16). The continuity and thickness of the crust will therefore depend on the relative supply of magma (which may itself vary with time and position) with respect to plate separation, and the seismic velocities that define the "crust" may be a complex function of composition, alteration and cracking of the lithosphere. Recent seismic studies at slow-spreading ridges have shown variations in crustal thickness and seismic velocities that are consistent with this compositionally heterogeneous lithospheric model [Barclay et al., 1998; Canales et al., 2000a; Canales et al., 2000b]. The size and distribution of the different lithologies are still largely unconstrained, due both to the lack of sufficiently high resolution seismic data, and to the impossibility of distinguishing seismically between lithologies such as partially serpentinized peridotite and gabbro [Carlson, 2001; Christensen, 1972; Horen et al., 1996].

Geological observations demonstrate that the crustal architecture and the processes responsible for its build up differ substantially from fast to slow-spreading ridges. Fast-spreading ridges display a homogeneous, layered crust that is formed with high melt supply and a relatively stable magmatic system (i.e., near-continuous axial magma chamber, frequent eruptions, etc.) In contrast, slow-spreading ridges show a wide range of crustal composition, structure and thickness, with important variations both regionally and along individual segments. This complexity arises from a discontinuous mode of magma emplacement (discrete gabbro bodies), and from a wide variation in the magma supply to the ridge axis, ranging from no magmatism (e.g., extension by pure stretching of the mantle lithosphere such as at Gakkel Ridge and parts of the South West Indian Ridge [Dick et al., 2003]), to well-developed and magmatically robust ridge segments that locally have crustal thicknesses exceeding 8 or $9 \mathrm{~km}$ (e.g., $\mathrm{OH} 1$ and Lucky Strike segments along the Mid-Atlantic Ridge [Escartín et al., 2001; Hooft et al., 2000], or other segments along the South West Indian Ridge [Cannat et al., 1999]). Realistic rheological models of mid-ocean ridges must treat fast- and slow-spreading ridges separately, as these systems operate differently, and do not appear to represent end-members of an accretion process with gradual variations in magma supply. These fundamental differences relate both to the composition and thermal structure of the lithosphere, and to the time-dependence of the processes involved in magmatic accretion and lithospheric construction.

\section{FAULTING AT MID-OCEAN RIDGES}

Tensional stresses induced by plate separation results in disruption of the upper crust (brittle lithosphere) by normal faults that dissect the ocean floor [Searle, 1992]. On the slowspreading Mid-Atlantic Ridge, most active faulting occurs within about 10-15 km of the ridge axis [McAllister and Cann, 1996; McAllister et al., 1995; Searle et al., 1998a]. The width of the active tectonic zone at fast-spreading ridges is less well constrained, though there is some evidence that it extends to $\sim 30 \mathrm{~km}$ off-axis [Macdonald, 1998]. Variations in faulting patterns regionally (e.g., fast vs. slow-spreading ridges) and locally (along individual segments) can therefore 
provide insight into the rheological structure of the lithosphere and its spatial variations.

High-angle faulting is responsible for the formation of abyssal hill terrain, and estimates of tectonic strain at the seafloor indicate that $<10-20 \%$ of the plate separation is taken up by such faulting [Allerton et al., 1996; Bohnenstiehl and Carbotte, 2001; Bohnenstiehl and Kleinrock, 1999; Carbotte and Macdonald, 1994; Carbotte et al., 2003; Escartin et al., 1999; Jaroslow et al., 1996; Macdonald and Luyendyk, 1977], while the rest must be taken up by magmatic emplacement or amagmatic accretion of mantle asthenosphere into the lithosphere. A similar value of $\sim 10 \%$ tectonic strain has been obtained from seismic moment release studies in the case of slow-spreading ridges [Solomon et al., 1988].

Faults are normally orthogonal to the spreading direction, except in oblique-spreading regions such as near hot spots and in proximity to NTDs. Faults identified in shipboard bathymetry and sonar data have a typical spacing on the order of 1-3 km, and lengths of tens of kilometers along the axial direction [Cowie et al., 1994; Macdonald et al., 1991a; Searle, 1984]. Faulting patterns at slow- and fast-spreading ridges differ substantially and reflect the fundamental differences in the structure and thermal state of the lithosphere under the axis in these two environments.

\subsection{NormalFaulting at Slow-Spreading Ridges}

Slow-spreading ridges are characterized by faults with throws that are an order of magnitude larger than those found at fast-spreading ridges (typically hundreds of meters to kilometers compared to $<100 \mathrm{~m}$ ). These faults are mostly facing the ridge axis, and produce a typical ridge-parallel abyssal hill terrain [Bohnenstiehl and Kleinrock, 2000; Goff, 1992; Tucholke et al., 1997] with vertical relief of $\sim 1 \mathrm{~km}$. The traces of faults show spatial variations that appear to be systematically linked to the geometry of slow-spreading ridge segments [Escartin et al., 1999; Escartin and Lin, 1995; Searle et al., 1998a; Shaw, 1992; Shaw and Lin, 1993]. At the centers of "typical" slow-spreading ridge segments, faults tend to define a symmetrical axial valley with similar fault size and strain distribution at each flank (Figure 15). Mature faults have moderate throws (a few hundred meters at most) and are spaced 1-2 km apart. These faults grow from individual small faults that link to form larger structures [Cowie and Scholz, 1992; Cowie et al., 1993; Searle et al., 1999; Searle et al., 1998a]. In contrast, segment ends are characterized by a marked asymmetry in topography and crustal thickness [Escartin and Lin, 1995; Severinghaus and Macdonald, 1988; Tucholke and Lin, 1994] that is associated with profound differences in fault patterns. It was early recognized that faults near segment ends had a larger throw and spacing that those near the segment center [Shaw, 1992], but the overall tectonic strain does not seem to vary between segment end and segment center [Escartin et al., 1999]. Asymmetry in tectonic strain can be important and extend along the whole length of a segment, and may be associated with a complementary asymmetry in magmatic accretion [Allerton et al., 2000; Escartin et al., 1999; Searle et al., 1998a].

These variations in fault patterns have been interpreted to reflect broad variations in the overall strength of slow-spreading oceanic lithosphere, with a thicker lithosphere at the segment end than at the center [Behn et al., 2002a; Behn et al., 2002b; Jaroslow, 1996; Shaw, 1992; Shaw and Lin, 1996]. Other processes, such as fault weakening due to alteration of the mantle (e.g., via serpentinisation) can promote efficient strain localization and therefore influence faulting patterns observed at the seafloor. While these studies have provided some insight into the expected variations in lithospheric thickness along ridge segments, an accurate interpretation of fault patterns in the light of the thermal state of the lithosphere, its composition, and the mode of strain localization is still required.

Numerical models incorporating processes such as fault weakening have been successful in reproducing, in two dimensions, the broad characteristics of seafloor topography at slowspreading ridges, with median valley and abyssal hills of the appropriate wavelength and height [Buck and Poliakov, 1998; Poliakov and Buck, 1998] (Plate 2a). These models incorporate an elastic-plastic-viscous layer, a temperature- and strainrate-dependant brittle to plastic transition, and fault weakening by the reduction of cohesion of fault material. The models, which do not include any magmatic accretion, predict strain localization along lithospheric-scale faults. These faults advect mantle asthenosphere whi ch is then accreted into the lithosphere. Models such as this demonstrate the importance of strain localisation in producing the observed ridge topography, and underline the importance of understanding the rheological properties that cause this to occur.

\subsection{Detachment Faulting}

Low-angle normal faults accommodating large amounts of displacement (detachment faults) have long been recognized in continental settings [Davis and Lister, 1988]. The presence of oceanic low-angle faults had been proposed early on [Dick et al., 2000; Dick et al., 1991; Dick et al., 1981; Karson and Dick, 1983; Mével et al., 1991] to explain the outcrop of basalt and gabbro, but the extent and geometry of the detachment fault surface was not defined. Oceanic detachments were first unambiguously identified on the Mid-Atlantic Ridge at $31^{\circ} \mathrm{N}$ [Cann et al., 1997], as smooth, curved and sub-horizontal surfaces with corrugations ("mullions") parallel to the spreading direction. Numerous such structures have now been iden- 

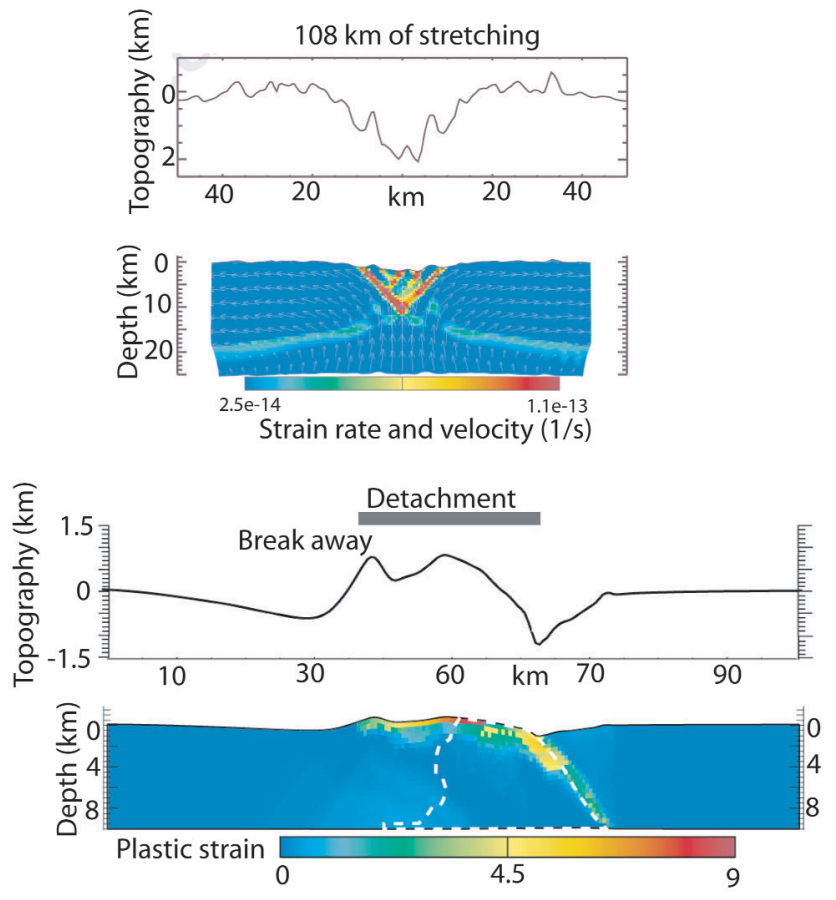

Plate 2. Numerical simulation of lithospheric stretching and strain localization. a: (top) Amagmatic stretching produces a seafloor topography that resembles that at slow-spreading ridges, with an axial valley and abyssal hills formed by many cross-cutting shear zones at the ridge axis [Buck and Poliakov, 1998]. b: (bottom) Detachment formation in numerical models that incorporate fault weakening. Under certain conditions deformation stabilizes for long periods of times and produces structures that have a similar geometry to the topography observed at oceanic detachments. The extent of the detachment is indicated by the grey bar, and the advection of mantle lithosphere can be tracked by the left-hand dashed white line, which indicates the present-day position of a marker originally at the base of the model [Lavier et al., 1999]. 
tified, surveyed and sampled along other sections of the MidAtlantic Ridge [Escartin and Cannat, 1999; Escartin et al., 2003; Fujiwara et al., 2003; MacLeod et al., 2002; Ranero and Reston, 1999; Reston et al., 2002; Tucholke et al., 1998; Tucholke et al., 2001], South West Indian Ridge [Dick et al., 2000; Searle et al., 2003], Central Indian Ridge [Mitchell, 1998], and back-arc basins [Ohara et al., 2001] (Plate 3). Oceanic detachments tend to occur near ridge offsets (mostly transforms), but occurrences of detachments away from offsets have also been identified on the Mid-Atlantic Ridge near the Fifteen-Twenty fracture zone [Escartin and Cannat, 1999; Fujiwara et al., 2003; MacLeod et al., 2002].

The presence of oceanic detachments implies that, during periods of time of the order of $1 \mathrm{Ma}$ or more, plate separation is accommodated mainly or entirely by pure tectonic extension in one flank of the ridge. Oceanic detachments have a limited along-axis extension, usually less than the length of the segment, so this highly asymmetric mode of plate separation must change abruptly from the detachment to adjacent areas. Neither the geometry of oceanic detachments (e.g., dip and depth of soling), nor the conditions of formation, deformation, and linkage to the adjacent seafloor, are properly understood. It has been proposed that these structures initiate as high-angle normal faults that then rotate by flexure [Buck, 1988; Tucholke et al., 1998], while other models propose that the fault flattens at depth and becomes sub horizontal, as proposed for Basin and Range detachments [Karson, 1990; Karson et al., 1987]. Oceanic detachments are proposed to root deeply near the brittle-plastic transition [Tucholke et al., 1998], at shallower levels in melt-rich zones such as the axial magma chamber [Dick et al., 2000], or within the brittle lithosphere at an alteration front [Escartin and Cannat, 1999; Escartin et al., 2003; MacLeod et al., 2002]. In all cases the root is placed at a rheological boundary that can localize deformation for long periods of time.

Oceanic detachments have been reproduced in numerical models that include the presence of strain softening to promote localization of deformation during long periods of time [Lavier et al., 1999] (Plate 2b). In these models, the onset of detachment faulting occurs for a rheology in which fault strength is reduced to $<10 \%$ of the total strength of the lithosphere. Such weakening mechanisms may be attained with alteration products such as serpentinite [Escartin et al., 1997a] or talc, but these phases are only stable in the shallow, cold lithosphere, and not near the brittle-plastic transition, as required by the numerical models. More recent numerical modeling incorporating magmatic accretion has shown a transition from mostly lithospheric extension at low magma supply to formation of detachments and asymmetric magmatic accretion when the magma supply is $\sim 50 \%$ of that corresponding to fully magmatic extension [Buck et al., 2003; Tucholke et al., 2003].
The presence of detachments throughout the oceanic crust, and their general, but not exclusive, association with transform offsets, NTDs, and the outcrop of serpentinized peridotites, indicates that their formation and development require specific conditions (e.g., of magma supply, temperature, lithospheric composition and geometry). It is also apparent that these conditions, while not unusual, are not found along all ridge segments or near all discontinuities. The existing numerical models, despite their limitations, support this qualitative interpretation; detachments form under certain rheologies that involve substantial weakening of the fault (allowing strain localization) and for a narrow range of magma supply to the ridge axis. Better understanding of the actual origin and conditions that lead to detachment fault development would provide important constraints on the thermal and rheological conditions at which they form.

\subsection{Lithospheric Deformation at Depth}

While most studies of tectonic strain at slow and fast-spreading ridges focus on faulting and deformation measurable at the seafloor as fault scarps [Bohnenstiehl and Carbotte, 2001; Bohnenstiehl and Kleinrock, 1999; Cowie, 1998; Escartin et al., 1999], geological evidence demonstrates that additional mechanisms of extension and tectonic uplift are active under the axis of slow-spreading ridges [Cannat and Casey, 1995]. Serpentinized peridotites outcropping along rift valley bounding fault scarps in the immediate vicinity of the active axial volcanic zone have been uplifted from the base of the lithosphere $\left(\sim 750^{\circ} \mathrm{C}\right)$ to the seafloor. Rift valley wall faults have vertical throws of $<2 \mathrm{~km}$, and therefore tectonic uplift associated with these fault scarps cannot exhume rocks from such depths. [Cannat and Casey, 1995] proposed the existence of a "tectonic lift" system of cross-cutting faults that allow the vertical ascent of rocks under the ridge axis from the base of the lithosphere to the seafloor. The nature and details of such uplift, required by the geological observations, is not constrained, though numerical models of pure stretching of the lithosphere [Buck and Poliakov, 1998] that simulate slow- spreading seafloor do show such patterns (Plate 2a). A similar mechanism is also required to operate along ridges with no magmatism, such as sections of the Gakkel Ridge [Michael et al., 2003].

\section{SUMMARY OF OBSERVATIONS: RHEOLOGICAL STRUCTURE OF SLOW AND FAST-SPREADING RIDGES}

The cartoons in Plate 4 are intended to summarize, in two dimensions, some of the main observations described above for both fast- and slow-spreading ridges and their relevance to the fundamental differences in the rheology under the ridge 

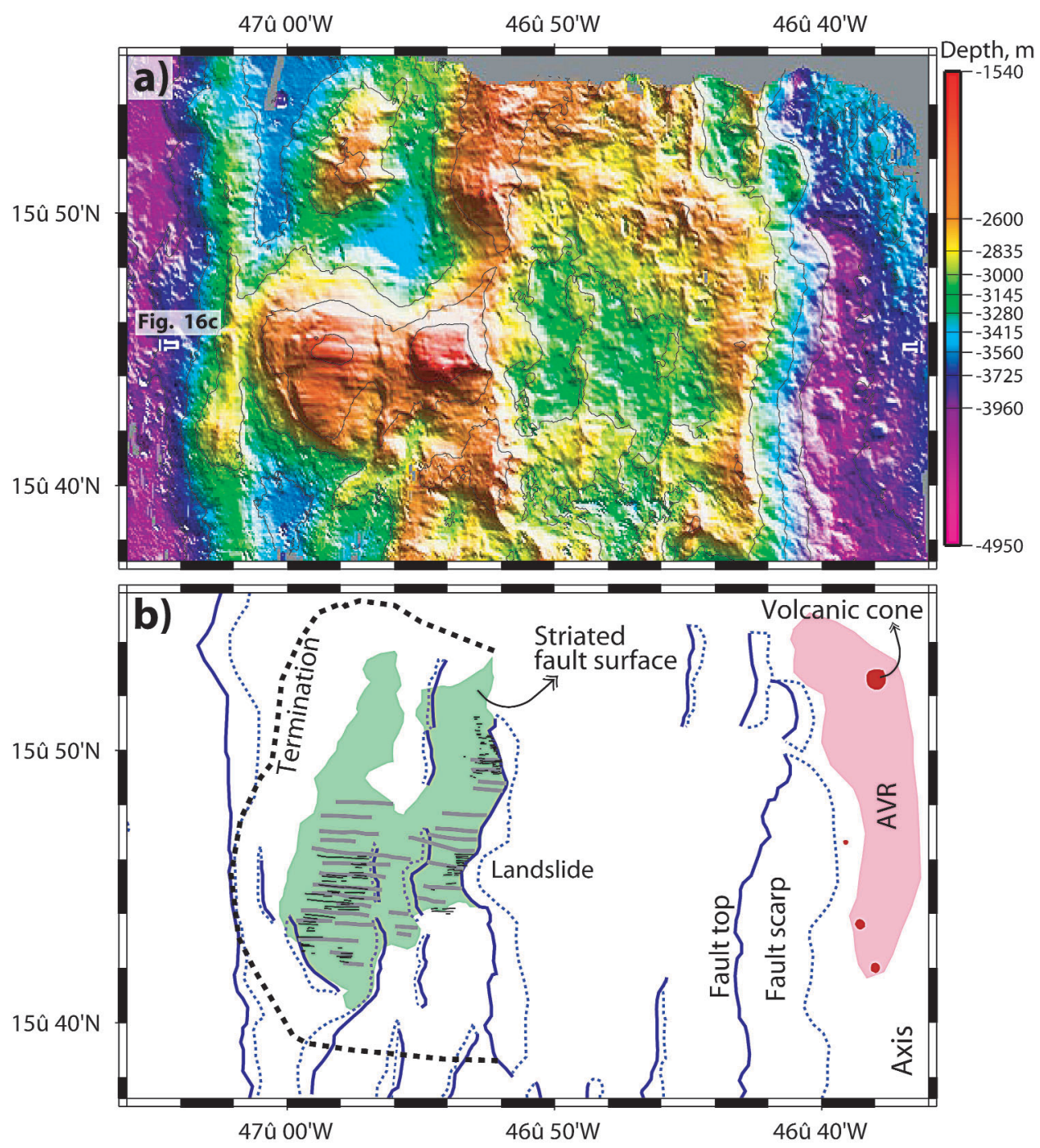

Plate 3. Shaded bathymetry (a, top) and geological interpretation (b, bottom) of the detachment off the Mid-Atlantic Ridge at $15^{\circ} 45^{\prime} \mathrm{N}$. The detachment is sub-horizontal and gently curved in the direction of spreading, and has bathymetric corrugations at wavelengths of $\sim 1 \mathrm{~km}$. The exposed fault surface (green in b) is up to $12 \mathrm{~km}$ wide. These detachment surfaces also show lineations at shorter wavelengths in the deep-tow sonar images, and fault striations at rock outcrops. After [Escartin et al., 2003] . 
axes. In addition, slow-spreading ridges in particular have further important along-axis variability.

Fast-spreading ridges (Plate $4 \mathrm{a}$ ) have a homogeneous, compositionally layered crust and little variation in crustal thickness. A magma chamber at $\sim 2 \mathrm{~km}$ depth is observed in numerous geophysical surveys, and additional magma chambers may be present in or below the crust. The thermal state of this type of ridge can be assumed to be quasi steady-state (when compared with that of slow-spreading ridges). The nature of the lower crust below the melt lens is not well constrained, but it is likely to be hot and may contain small amounts of partial melt, at least locally. Seismic data [Hammond and Toomey, 2003; MELT, 1998] suggest that the isotherms are steeply dipping at the flanks of the magma chamber, and that hydrothermal circulation is vigorous and reaching deep levels below the magma chamber adjacent to it. The brittle to plastic transition is likely to have a large amount of variation in depth at short distances from the axis, being controlled primarily by the presence of the axial magma chamber. We expect two areas of deformation; a near-axis one with development of smaller faults and dyking feeding axial volcanism, and off-axis growth of faults over the thicker lithosphere away from the melt lens.

The structure, composition and geometry of the lithosphere under the axis of slow-spreading ridges is not as well constrained, and probably has a large variability both in composition and temperature, varying both spatially (along and across-axis) and temporally (Plate 4b). The brittle lithosphere is, over large time scales, thicker than that at fast-spreading ridges, allowing the development of larger faults. Detachments accommodating large amounts of extension may form under certain rheological conditions that are yet to be determined. There is ample evidence of strain localization along ductile shear zones in the upper asthenosphere and lower mantle lithosphere at temperatures $<700^{\circ} \mathrm{C}$, that are frozen into the lithosphere and rafted off-axis. These shear zones may be connected with brittle zones at higher levels to allow the tectonic uplift of mantle rocks in close proximity to the ridge axis. Magma chambers are ephemeral, and may substantially alter the thermal structure and therefore the lithospheric rheology, with a transient position of the brittle to plastic transition. Other rheological boundaries may play a role in determining the mode of fault localization, such as the serpentinite alteration front associated with hydrothermal circulation and hydration of the upper lithosphere. Finally, the composition of the lithosphere may range from pure amagmatic (i.e., mantle lithosphere exposed at the seafloor) to a continuous magmatic crust formed by episodic intrusion and extrusion of magma.

Although constraints on the structure and composition of fast-spreading ridges are better than those for slow-spread- ing ones, both systems require additional constraints to obtain realistic rheological models. These are in turn needed to provide further insights into processes that take place at these systems (e.g., faulting) and to provide a sound basis for the interpretation of geological observations such as faulting and naturally deformed rocks in terms of lithospheric rheology.

\section{CONCLUSIONS}

We have shown that, to a first order, the rheology of the lithosphere depends on its thermal state, and on the composition, abundance, distribution and mechanical properties of its components. Phases that are not abundant (such as alteration products) may play an important role in both the overall strength of the lithosphere and the mode of localization of the deformation, and need to be fully characterized and incorporated into rheological models. The final lithospheric rheology determines the mode of faulting, dyking and volcanic emplacement, and is ultimately responsible for the morphology of the seafloor and the distribution of faults that we observe. While simple thermo-mechanical models have provided great insight into important processes such as rift valley formation, interpretation of seafloor morphology and faulting in terms of lithospheric rheology has been hindered by a lack of actual constraints on the detailed thermal structure, composition and architecture of the lithosphere under the axis of both fast- and slow-spreading ridges.

Results from experimental rock mechanics have formed the basis for all rheological models commonly used, but require major extrapolation of the experimental results from laboratory to natural conditions. To date, we have gained a good understanding of the mechanical properties of olivine and olivine aggregates, and a body of experimental data exists for dolerite and serpentinite, including the important role of both melt and water: these are all important components of the oceanic lithosphere. This type of experimental work needs to be extended to other lithologies, such as the alteration products of the crust and mantle (i.e., amphibolites, talc, etc.), and the role of water, melt, and other parameters such as compositional variations in individual rock types need to be better characterized.

The main structure and composition of mid-ocean ridges, particularly of fast-spreading ones, is relatively well known thanks to detailed geophysical images of the crust and upper mantle. In the case of slow-spreading ridges, important remaining unknowns are the relative abundance, distribution and geometry of different lithologies (mainly gabbro, peridotite and serpentinite, but also the way in which dolerite and basalt are distributed at so-called "magmatic" and "amagmatic" crust); these are all required parameters to construct robust rheological models. In neither fast- nor slow-spread- 

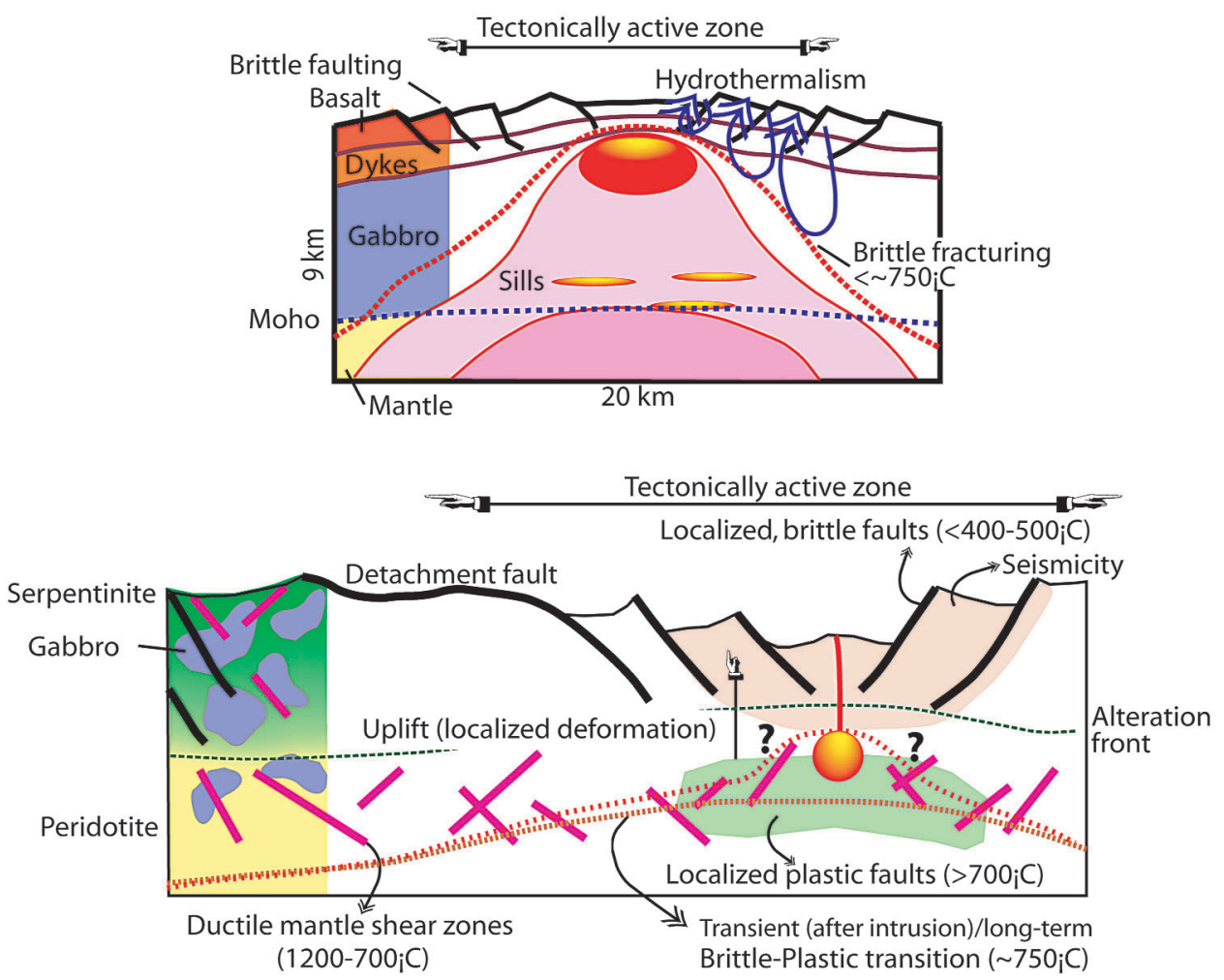

Plate 4. Schematic representation of the rheological structure of the lithosphere across the axis of fast- and slow-spreading ridges. While the fast-spreading system may show a steady magma chamber and the formation of a compositionally homogeneous crust, the slow-spreading system shows ephemeral magma chambers emplaced in the lithosphere and resulting in a heterogeneous composition. a: (top) Fast-spreading ridge. Coloring at left emphasizes simple layered lithological structure of crust formed at such ridges. Thin red lines represent isotherms, and thick dashed line is approximate $750^{\circ} \mathrm{C}$ isotherm representing brittle-plastic transition. Red areas represent crystal mush zones, grading into yellow representing magma chambers with more continuous melt. High-level sub-axial melt zone is quasi-continuous. Blue lines schematically represent hydrothermal circulation. b: (bottom) Slow-spreading ridge. Magmatism is highly discontinuous in space and time: orange-dashed line shows long-term brittle-plastic transition, while red-dashed line shows BPT immediately following transient magma injection. Melt is shown schematically grading from crystal mush zone (red) into connected magma (yellow), though the detailed geometry of the melt zone is unknown. Lithological structure may be highly heterogeneous. Shown on the left is an extreme case of "amagmatic" crust (typical of detachment zones, segment ends and parts of very cold or slowspreading ridges) where the basaltic layer is absent; at other parts of slow-spreading ridges, and especially segment centers, there may be a basaltic carapace, possibly overlying a sheeted dyke layer (see Figure 16). Fine black dashed line schematically indicates the serpentinisation (peridotite alteration) front, which occurs at approximately $450^{\circ} \mathrm{C}$ and is probably limited by the depth of hydrothermal circulation. Upper crust is deformed by brittle faulting (black lines), while lower (and, locally, upper) crust and mantle are deformed in ductile shear zones. Hydrothermal activity (not shown) is probably highly episodic at slow-spreading ridges. See text for further discussion and explanation. 
ing ridges are there yet good constraints on the distribution of melt and water. Finally, the thermal structure of fast-spreading ridges is relatively well determined, as the presence of the geophysically imaged magma lens imposes clear thermal constraints. In contrast, slow-spreading ridges probably display a thermal structure that varies substantially with time, as a consequence of emplacement of discrete magma bodies of unknown size and at unknown rates, but details are at present very poorly constrained.

To date, thermo-mechanical models have been successful in reproducing first-order observables such as the axial relief and general faulting patterns. These models can also reproduce structures such as oceanic detachments, although they do not fully explain all available geological observations, nor yet take into account parameters such as the compositional heterogeneity of the lithosphere. Magmatic accretion and its interplay with tectonism is an important but complex process that operates at mid-ocean ridges, and is just beginning to be incorporated into such models. The combined geological and theoretical study of the formation and evolution of detachments can provide valuable information on the rheological conditions at which these structures form, giving clues to the actual rheological state of different parts of the oceanic lithosphere.

Due to the numerous processes controlling the rheological structure of the lithosphere, there is no simple and direct correlation between fault structure and seafloor morphology on the one hand, and on the other the mechanical properties of the lithosphere at depth. A good understanding of this link will require further observations on the composition, thermal structure and processes operating near ridge axes as recorded by naturally deformed rocks, additional experimental work on the mechanical properties of different rock types that are present in the lithosphere, and the development of rheological models that capture the complexity of natural systems, including the interaction of magmatism and tectonism, the temporal variability of these processes, and the heterogeneous nature of the oceanic lithosphere, particularly at slowspreading ridges.

Acknowledgements. This paper was developed from a presentation on the "Thermal Regime of Ocean Ridges and Dynamics of Hydrothermal Circulation" delivered at the first InterRidge Theoretical Institute held in Pavia, Italy in September 2002. We want to acknowledge the stimulating presentations and discussions with the participants of this meeting that have made their way into this paper. In particular the comments, encouragement and persistence of Jian Lin made this paper possible. The paper was largely finalized while RCS was on sabbatical at Woods Hole Oceanographic Institution, and he is grateful for interactions with many colleagues there. The final paper benefited greatly from careful reviews by Roger Buck, Patience Cowie and Greg Hirth. Both authors gratefully acknowledge travel support from the European Science Foundation to Pavia, and RCS acknowledges support from the Leverhulme Trust for his stay at Woods Hole.

\section{REFERENCES}

Abelson, M., and A. Agnon, Mechanics of oblique spreading and ridge segmentation, Earth and Planetary Science Letters, 148, 405-421, 1997.

Agar, S. M., and F. C. Marton, Microstructural controls on strain localization in ocean diabases: Evidence from Hole 504B, in Proceedings of the Ocean Drilling Program, Scientific Results, edited by J. Erzinger, H. J. B. Dick, L. B. Stokking, and e. al., pp. 219-229, Ocean Drilling Program, College Station, TX, 1995.

Allerton, S., J. Escartin, and R. C. Searle, Extremely asymmetric magmatic accretion of oceanic crust at the ends of slow-spreading ridge-segments, Geology, 28, 179-182, 2000.

Allerton, S., R. C. Searle, and B. J. Murton, Bathymetric segmentation and faulting on the Mid-Atlantic Ridge, $24^{\circ} 00^{\prime} \mathrm{N}$ to $24^{\circ} 40^{\prime} \mathrm{N}$, in Tectonic, Magmatic, Hydrothermal and Biological Segmentation of Mid-Ocean Ridges, Geological Society of London, Special Publication 118, edited by C. J. MacLeod, P. A. Tyler, and C. L. Walker, pp. 49-60, 1996.

Atwater, T., and J. D. Mudie, Block faulting on the Gorda Rise, Science, 159, 729-731, 1968.

Aumento, F., and H. Loubat, The Mid-Atlantic Ridge near $45^{\circ} \mathrm{N}$. XVI. Serpentinized ultramafic intrusions, Canadian Journal of Earth Science, 8, 631-663, 1971.

Auzende, J.-M., D. Bideau, E. Bonatti, M. Cannat, J. Honnorez, Y. Lagabrielles, J. Malaveille, V. Mamaloukas-Frangoulis, and C. Mevel, Direct observation of a section through slow-spreading oceanic crust, Nature, 337, 726-729, 1989.

Babcock, J. M., A. J. Harding, G. M. Kent, and J. A. Orcutt, An examination of along-axis variation of magma chamber width and crustal structure on the East Pacific Rise between $13^{\circ} 30^{\prime} \mathrm{N}$ and $12^{\circ} 20^{\prime} \mathrm{N}$, Journal of Geophysical Research, 103 (B12), 30371-30384, 1998.

Ballard, R. D., and T. H. Van Andel, Morphology and tectonics of the inner rift valley at lat. $36^{\circ} 50^{\prime} \mathrm{N}$ on the Mid-Atlantic Ridge, Geological Society of America Bulletin, 88, 507-530, 1977.

Barclay, A. H., D. R. Toomey, and S. C. Solomon, Seismic structure and crustal magmatism at the Mid-Atlantic Ridge, $35^{\circ} \mathrm{N}$, Journal of Geophysical Research, 103 (B8), 17827-17844, 1998.

Barclay, A. H., D. R. Toomey, and S. C. Solomon, Microearthquake characteristics and crustal $\mathrm{Vp} / \mathrm{Vs}$ structure at the Mid-Atlantic Ridge, $35^{\circ} \mathrm{N}$, Journal of Geophysical Research-Solid Earth, 106 (B2), 2017-2034, 2001.

Barnouin-Jha, K., E. M. Parmentier, and D. W. Sparks, Buoyant mantle upwelling and crustal production at oceanic spreading centers: On-axis segmentation and off-axis melting, Journal of Geophysical Research, 102 (B6), 11979-11989, 1997.

Bazin, S., A. J. Harding, G. M. Kent, J. A. Orcutt, C. H. Tong, J. W. Pye, S. C. Singh, P. J. Barton, M. C. Sinha, R. S. White, R. W. Hobbs, and H. J. A. Van Avendonk, Three-dimensional shallow crustal emplacement at the $9^{\circ} 03^{\circ} \mathrm{N}$ overlapping spreading center on the East Pacific Rise: Correlations between magnetization and 
tomographic images, Journal of Geophysical Research, 106 (B8), 16101-16117, 2001.

Bazin, S., H. van Avendonk, A. J. Harding, J. A. Orcutt, J. P. Canales, and R. S. Detrick, Crustal structure of the flanks of the East Pacific Rise: Implications for overlapping spreading centers, Geophysical Research Letters, 25 (12), 2213-2216, 1998.

Behn, M., J. Lin, and M. T. Zuber, Mechanisms of normal fault development at mid-ocean ridges, Journal of Geophysical Research, 107 (B4), 10.1029/2001JB000503, 2002a.

Behn, M. D., J. Lin, and M. T. Zuber, A continuum mechanics model for normal faulting using a strain-rate softening rheology: implications for thermal and rheological controls on continental and oceanic rifting, Earth and Planetary Science Letters, 202 (3-4), 725-740, 2002b.

Bell, R. E., and W. R. Buck, Crustal control of ridge segmentation inferred from observations of the Reykjanes Ridge, Nature, 357, 583-586, 1992.

Bergman, E. A., and S. C. Solomon, Earthquake swarms on the MidAtlantic Ridge: Products of magmatism or extensional tectonics?, Journal of Geophysical Research, B, 95 (4), 4943-4965, 1990.

Blacic, J. D., and J. M. Christie, Plasticity and hydrolitic weakening of quartz single crystals, Journal of Geophysical Research, 89 (B6), 4223-4239, 1984.

Blackman, D. K., J. R. Cann, B. Janssen, and D. K. Smith, Origin of extensional core complexes: Evidence from the Mid-Atlantic Ridge at Atlantis Fracture Zone, Journal of Geophysical Research, $B, 103,21,315-21,333,1998$.

Bohnenstiehl, D. R., and S. M. Carbotte, Faulting patterns near $19^{\circ} 30^{\prime} \mathrm{S}$ on the East Pacific Rise: Fault formation and growth at a superfast spreading center, Geochemistry Geophysics Geosystems, 2, art. no. 2001GC000156, 2001.

Bohnenstiehl, D. R., and M. C. Kleinrock, Faulting and fault scaling on the median valley floor of the trans-Atlantic geotraverse (TAG) segment, $\sim 26^{\circ} \mathrm{N}$ on the Mid-Atlantic Ridge, Journal of Geophysical Research-Solid Earth, 104 (B12), 29351-29364, 1999.

Bohnenstiehl, D. R., and M. C. Kleinrock, Evidence for spreadingrate dependence in the displacement-length ratios of abyssal hill faults at mid-ocean ridges, Geology, 28 (5), 395-398, 2000.

Bonatti, E., and P. R. Hamlyn, Mantle uplifted blocks in the western Indian Ocean, Science, 201, 249-251, 1978.

Bonatti, E., and C. G. A. Harrison, Hot lines in the Earth's mantle, Nature, 263, 402-404, 1976.

Bos, B., C. J. Peach, and C. J. Spiers, Slip behaviour of simulated gouge-bearing faults under conditions favoring pressure solution, Journal of Geophysical Research, 105 (B7), 16699-16717, 2000.

Bott, M. H. P., Flexure associated with planar faulting, Geophysical Journal International, 126, F21-F24, 1996.

Bowin, C. O., and J. Milligan, Negative gravity anomaly over spreading rift vcalleys: Mid-Atlantic Ridge at $26^{\circ} \mathrm{N}$, Tectonophysics, 113 (233-256), 1985.

Brace, W. F., and D. L. Kohlstedt, Limits on lithospheric stress imposed by laboratory experiments, Journal of Geophysical Research, 85, 6248-6252, 1980.

Buck, R. W., L. Lavier, and A. Poliakov, Modes of faulting at midocean ridges, in EGS-AGU-EUG Joint Assembly, pp. EAE03-A133333, EGS, Nice, France, 2003.
Buck, W. R., Flexural rotation of normal faults, Tectonics, 7 (5), 959-973, 1988.

Buck, W. R., Accretional curvature of lithosphere at magmatic spreading centers and the flexural support of axial highs, Journal of Geophysical Research, 106 (B3), 3953-3960, 2001.

Buck, W. R., and A. N. B. Poliakov, Abyssal hills formed by stretching oceanic lithosphere, Nature, 392, 272-275, 1998.

Bunch, A. W. H., and B. L. N. Kennett, The crustal structure of the Reykjanes Ridge at $59^{\circ} 30^{\prime} \mathrm{N}$, Geophysical Journal of the Royal Astronomical Society, 61, 141-166, 1980.

Byerlee, J. D., Brittle-ductile transition in rocks, Journal of Geophysical Research, 73, 4741-4750, 1968.

Byerlee, J. D., Friction of rocks, Pure and Applied Geophysics, 116, 615-626, 1978.

Caldwell, J. G., W. F. Haxby, D. E. Karig, and D. L. Turcotte, On the applicability of a universal elastic trench profile, Earth and Planetary Science Letters, 31 (239-246), 1976.

Canales, J. P., J. A. Collins, J. Escartin, and R. S. Detrick, Seismic structure across the rift valley of the Mid-Atlantic Ridge at $23^{\circ} 20^{\prime}$ (MARK area): Implications for crustal accretion processes at slow spreading ridges, Journal of Geophysical Research-Solid Earth, 105 (B12), 28411-28425, 2000a.

Canales, J. P., J. J. Dañobeitia, R. S. Detrick, E. E. E. Hooft, R. Bartolomé, and D. F. Naar, Variations in axial morphology along the Galápagos spreading center and the influence of the Galápagos hotspot, Journal of Geophysical Research, 102 (B12), 27341-27354, 1997.

Canales, J. P., R. S. Detrick, S. Bazin, A. J. Harding, and J. A. Orcut, Off-axis crustal thickness across and along the East Pacific Rise within the MELT area, Science, 280, 1218-1221, 1998.

Canales, J. P., R. S. Detrick, J. Lin, J. A. Collins, and D. R. Toomey, Crustal and upper mantle seismic structure beneath the rift mountains and across a nontransform offset at the Mid-Atlantic Ridge $\left(35^{\circ} \mathrm{N}\right)$, Journal of Geophysical Research-Solid Earth, 105 (B2), 2699-2719, 2000b.

Cann, J. R., D. K. Blackman, D. K. Smith, E. McAllister, B. Janssen, S. Mello, E. Avgarinos, A. R. Pascoe, and J. Escartin, Corrugated slip surfaces formed at ridge-transform intersections on the Mid Atlantic Ridge, Nature, 385, 329-332, 1997.

Cannat, M., Emplacement of mantle rocks in the seafloor at midocean ridges, Journal of Geophysical Research, 98 (B3), 4163-4172, 1993.

Cannat, M., How thick is the magmatic crust at slow-spreading midocean ridges?, Journal of Geophysical Research, 101 (B2), 2847-2857, 1996.

Cannat, M., and J. F. Casey, An ultramafic lift at the Mid-Atlantic Ridge: Successive stages of magmatism in serpentinized peridotites from the $15^{\circ} \mathrm{N}$ region, in Mantle and Lower Crust Exposed in Oceanic Ridges and in Ophiolites, edited by R.L.M. Vissers, and A. Nicolas, pp. 5-34, Kluwer Academic Publishers, The Netherlands, 1995.

Cannat, M., Y. Lagabrielle, H. Bougault, J. Casey, N de Coutures, L. Dmitriev, and Y. Fouguet, Ultramafic and gabbroic exposures at the Mid-Atlantic Ridge: Geological mapping in the $15^{\circ} \mathrm{N}$ region, Tectonophysics, 279, 193-213, 1997.

Cannat, M., C. Mevel, M. Maia, C. Deplus, C. Durand, P. Gente, P. 
Agrinier, A. Belarouchi, G. Dubuisson, E. Humler, and J. Reynolds, Thin crust, ultramafic exposures, and rugged faulting patterns at Mid-Atlantic Ridge $\left(22^{\circ}-24^{\circ} \mathrm{N}\right)$, Geology, 23 (1), 49-52, 1995.

Cannat, M., C. Rommevaux-Jestin, D. Sauter, C. Deplus, and V. Mendel, Formation of the axial relief at the very slow spreading Southwest Indian Ridge $\left(49^{\circ}-69^{\circ}\right)$, Journal of Geophysical Research, 104 (B10), 22,825-22,843, 1999.

Carbotte, S. M., and K. C. Macdonald, Comparison of seafloor tectonic fabric at intermediate, fast, and super fast spreading ridges: Influence of spreading rate, plate motions, and ridge segmentation on fault patterns, Journal of Geophysical Research, 99 (B7), 13,609-13,631, 1994.

Carbotte, S. M., W. B. F. Ryan, W. Jin, M.-H. Cormier, E. Bergmanis, J. Sinton, and S. White, Magmatic subsidence of the East Pacific Rise (EPR) at $18^{\circ} 14^{\prime}$ 'S revealed through fault restoration of ridge crest bathymetry, Geochemistry, Geophysics and Geosystems, 3 (1), doi:10.1029/2002GC000337, 2003.

Caristan, Y., The transition from high temperature creep to fracture in Maryland diabase, Journal of Geophysical Research, 87, 6781-6790, 1982.

Carlson, R. L., The abundance of ultramafic rocks in Atlantic Ocean crust, Geophysical Journal International, 144 (1), 37-48, 2001.

Cazenave, A., B. Lago, K. Dominh, and K. Lambeck, On the response of the ocean lithosphere to seamount loads from Geos 3 satellite radar altimeter observations, Geophysical Journal of the Royal Astronomical Society, 63 (233-252), 1980.

Chen, Y., and W. J. Morgan, A nonlinear rheology model for midocean ridge axis topography, Journal of Geophysical Research, 95, 17583-17604, 1990a.

Chen, Y., and W. J. Morgan, Rift valley/no rift valley transition at mid-ocean ridges, Journal of Geophysical Research, 95, 17571-17581, 1990b.

Chen, Y. J., The thermal state of the oceanic crust, in InterRidge Theoretical Institute: Thermal Regime of Ocean Ridges and Dynamics of Hydrothermal Circulation, edited by C. German, J. Lin, R. Tribuzio, A. Fisher, M. Cannat, and A. Adamczewska, pp. 10, InterRidge, Tokyo, 2003.

Chopra, P. N., The plasticity of some fine-grained aggregates of olivine at high pressure and temperature, in Mineral and rock deformation: Laboratory studies, edited by H. E. Hobbs, and $\mathrm{H}$. C. Heard, pp. 25-33, American Geophysical Union, Washington D. C., 1986.

Chopra, P. N., and M. S. Paterson, The role of water in the deformation of dunite, Journal of Geophysical Research, 89, 7861-7876, 1984.

Christensen, N. I., The abundance of serpentinites in the oceanic crust, Journal of Geology, 80, 709-719, 1972.

Coakley, B. J., and J. R. Cochran, Gravity evidence of very thin crust at the Gakkel Ridge (Arctic Ocean), Earth and Planetary Science Letters, 162, 81-95, 1998.

Cochran, J. R., An analysis of isostasy in the worlds oceans: 2. Midocean ridge crests, Journal of Geophysical Research, 84 (4713-4729), 1979.

Cochran, J. R., G. J. Kurras, M. H. Edwards, and B. J. Coakley, The Gakkel Ridge: Bathymetry, gravity anomalies, and crustal accretion at extremely slow spreading rates, Journal of Geophysical Research, 108 (B2), 10.1029/2002JB001830, 2003.
Coogan, L. A., G. R. T. Jenkin, and R. N. Wilson, Constraining the cooling rate of the lower oceanic crust: a new approach applied to the Oman ophiolite, Earth and Planetary Science Letters, 199 (1-2), 127-146, 2002.

Cowie, P. A., Normal Fault Growth in 3D in Continental and Oceanic Crust, in Faulting and Magmatism at Mid-Ocean Ridges, edited by W. R. Buck, P. T. Delaney, J. A. Karson, and Y. Lagabrielle, pp. 325-348, American Geophysical Union, 1998.

Cowie, P. A., A. Malinverno, W. B. F. Ryan, and M. H. Edwards, Quantitative fault studies on the East Pacific Rise: A comparison of sonar imaging techniques, Journal of Geophysical Research, 99 (B8), 15205-15218, 1994.

Cowie, P. A., and C. H. Scholz, Displacement-length scaling relationship for faults: Data synthesis and discussion, Journal of Structural Geology, 14, 1149-1156, 1992.

Cowie, P. A., C. H. Scholz, M. Edwards, and A. Malinverno, Fault strain and seismic coupling on mid-ocean ridges, Journal of Geophysical Research, 98, 17,911-17,920, 1993.

Crawford, W. C., and S. C. Webb, Variations in the distribution of magma in the lower crust and at the Moho beneath the East Pacific Rise at $9-10^{\circ} \mathrm{N}$, Earth and Planetary Science Letters, 203 (1), 117-130, 2002.

Davis, E. E., and C. R. B. Lister, Fundamentals of ridge crest topography, Earth and Planetary Science Letters, 21, 405-413, 1974.

Davis, G., and G. Lister, Detachment faulting in continental extension: Perspectives from the southwestern US Cordillera, Geological Society of America Special Paper, 218, 133-159, 1988.

Detrick, R., J. Collins, and S. Swift, In situ evidence for the nature of the seismic layer 2/3 boundary in oceanic crust, Nature, 370 , 288-290, 1994.

Detrick, R. S., J. C. Mutter, P. Buhl, and I. I. Kim, No evidence from multichannel reflection data for a crustal magma chamber in the MARK area on the Mid-Atlantic Ridge, Nature, 347, 61-64, 1990.

Detrick, R. S., H. D. Needham, and V. Renard, Gravity anomalies and crustal thickness variations along the Mid-Atlantic Ridge between $33^{\circ} \mathrm{N}$ and $40^{\circ} \mathrm{N}$, Journal of Geophysical Research, 100 (B3), 3767-3787, 1995.

Dick, H., J. Lin, and H. Schouten, An ultra-slow-spreading class of ocean ridge, Nature, 426, 405-412, 2003.

Dick, H. J. B., Abyssal peridotites, very slow spreading ridges and ocean ridge magmatism, in Magmatism in the Ocean Basins, edited by A. D. Saunders, and M. J. Norry, pp. 71-105, Geological Society, London, 1989.

Dick, H. J. B., J. H. Natland, J. C. Alt, W. Bach, D. Bideau, J. S. Gee, S. Haggas, J. G. H. Hertogen, G. Hirth, P. M. Holm, B. Ildefonse, G. J. Iturrino, B. E. John, D. S. Kelley, E. Kikawa, A. Kingdon, P. J. LeRoux, J. Maeda, P. S. Meyer, D. J. Miller, H. R. Naslund, Y. L. Niu, P. T. Robinson, J. Snow, R. A. Stephen, P. W. Trimby, H. U. Worm, and A. Yoshinobu, A long in situ section of the lower ocean crust: results of ODP Leg 176 drilling at the Southwest Indian Ridge, Earth and Planetary Science Letters, 179 (1), 31-51, 2000.

Dick, H. J. B., H. Schouten, P. S. Meyer, D. G. Gallo, H. Bergh, R. Tyce, P. Patriat, K. T. M. Johnson, J. Snow, and A. Fisher, Tectonic evolution of the Atlantis II Fracture Zone, Proceedings of the Ocean Drilling Program, Scientific Results, 118, 359-398, 1991.

Dick, H. J. B., W. B. Thompson, and W. B. Bryan, Low angle fault- 
ing and steady-state emplacement of plutonic rocks at ridge-transform intersections, EOS, Transactions, American Geophysical Union, 62, 406, 1981.

Dunn, R. A., D. R. Toomey, and S. C. Solomon, Three-dimensional seismic structure and physical properties of the crust and shallow mantle beneath the East Pacific Rise at 9 degrees 30'N, Journal of Geophysical Research-Solid Earth, 105 (B10), 23537-23555, 2000.

Durham, W. B., and C. Goetze, Plastic flow of oriented single crystals of olivine, 1, mechanical data, Journal of Geophysical Research, 82 (36), 5737-5753, 1977.

Durham, W. B., C. Goetze, and B. Blake, Plastic flow of oriented single crystals of olivine. 2 Observations and interpretations of the dislocation structures, Journal of Geophysical Research, 82 (36), 5755-5770, 1977.

Eberle, M. A., and D. W. Forsyth, An alternative, dynamic model of the axial topographic high at fast spreading ridges, Journal of Geophysical Research, B, 103, 12,309-12,320, 1998.

Engel, C. G., and R. L. Fischer, Granitic to ultramafic rock complexes of the Indian Ocean ridge system, western Indian Ocean, Geological Society of America Bulletin, 86, 1553-1578, 1953.

Escartin, J., and M. Cannat, Ultramafic exposures and the gravity signature of the lithosphere near the Fifteen-Twenty Fracture Zone (Mid-Atlantic Ridge, $14^{\circ}-16.5^{\circ} \mathrm{N}$ ), Earth and Planetary Science Letters, 171, 411-424, 1999.

Escartin, J., M. Cannat, G. Pouliquen, A. Rabain, and J. Lin, Crustal thickness of V-shaped ridges south of the Azores: Interaction of the Mid-Atlantic Ridge $\left(36^{\circ}-39^{\circ} \mathrm{N}\right)$ and the Azores hot spot, Journal of Geophysical Research, 106 (B10), 21,719-21,735, 2001.

Escartin, J., P. A. Cowie, R. C. Searle, S. Allerton, N. C. Mitchell, C. J. MacLeod, and P. A. Slootweg, Quantifying tectonic strain and magmatic accretion at a slow-spreading ridge segment, MidAtlantic Ridge, $29^{\circ} \mathrm{N}$, Journal of Geophysical Research, B, 104, 10,421-10,437, 1999.

Escartin, J., G. Hirth, and B. Evans, Effects of serpentinization on the lithospheric strength and the style of normal faulting at slowspreading ridges, Earth and Planetary Science Letters, 151, 181-189, 1997a.

Escartin, J., G. Hirth, and B. Evans, Nondilatant brittle deformation of serpentinites: Implications for Mohr-Coulomb theory and the strength of faults, Journal of Geophysical Research, 102 (B2), 2897-2913, 1997b.

Escartín, J., G. Hirth, and B. Evans, Strength of slightly serpentinized peridotites: Implications of the tectonics of oceanic lithosphere, Geology, 29 (11), 1023-1026, 2001.

Escartin, J., and J. Lin, Ridge offsets, normal faulting, and gravity anomalies of slow spreading ridges, Journal of Geophysical Research, 100 (B4), 6163-6177, 1995.

Escartin, J., and J. Lin, Tectonic modification of axial structure: Evidence from spectral analyses of gravity and bathymetry of the Mid-Atlantic Ridge flanks $\left(25.5^{\circ}-17.5^{\circ} \mathrm{N}\right)$, Earth and Planetary Science Letters, 154 (1-4), 279-293, 1998.

Escartin, J., C. Mevel, C. J. MacLeod, and A. M. McCaig, Constraints on deformation conditions and the origin of oceanic detachments: The Mid-Atlantic Ridge core complex at $15^{\circ} 45^{\prime} \mathrm{N}$, Geochemistry Geophysics Geosystems, 4, art. no. 1067, 2003.
Evans, B., and C. Goetze, The temperature variation of hardness of Olivine and its implication for polycrystalline yield stress, Journal of Geophysical Research, 84 (B10), 5505-5524, 1979.

Evans, B., and D. L. Kohlstedt, Rheology of Rocks, in Rock physics and phase relations: A handbook of physical constants, edited by T. J. Ahrens, pp. 148-165, American Geophysical Union, Washington, D.C., 1995.

Fox, P. J., N. R. Grindlay, and K. C. Macdonald, The Mid-Atlantic Ridge ( $\left.31^{\circ} \mathrm{S}-34^{\circ} 30^{\prime} \mathrm{S}\right)$ : Temporal and Spatial Variations of Accretionary Processes, Marine Geophysical Researches, 13, 1-20, 1991.

Fredrich, J. T., B. Evans, and T. F. Wong, Micromechanics of the brittle to plastic transition in Carrara marble, Journal of Geophysical Research, 94 (B4), 4129-4145, 1989.

Früh-Green, G. L., A. Plas, and L. N. Dell'Angelo, Mineralogic and stable isotope record of polyphase alteration of upper crustal gabbros of the East Pacific Rise (Hess Deep, Site 894), in Proceedings of the Ocean Drilling Program, Scientific Results, edited by C. Mével, K. M. Gillis, J. F. Allan, and P. S. Meyer, pp. 235-254, Ocean Drilling Program, College Station, TX, 1996.

Fujimoto, H., M. Cannat, K. Fujioka, T. Gamo, C. German, C. Mével, U. Münch, S. Ohta, M. Oyaizu, L. Parson, R. Searle, Y. Sohrin, and T. Yama-ashi, First Submersible Investigations of the mid-ocean ridges in the Indian Ocean, InterRidge News, 8, 22-24, 1999.

Fujiwara, T., J. Lin, T. Matsumoto, P. B. Kelemen, B. E. Tucholke, and J. F. Casey, Crustal evolution of the Mid-Atlantic Ridge near Fifteen-Twenty Fracture Zone in the last $5 \mathrm{Ma}$, Geochemistry, Geophysics, Geosystems, 4, article 1024, doi:10.1029/2002GC000364, 2003.

Garrido, C. J., P. B. Kelemen, and G. Hirth, Variation of cooling rate with depth in lower crust formed at an oceanic spreading ridge: Plagioclase crystal size distributions in gabbros from the Oman ophiolite, Geochemistry, Geophysics, Geosystems, 2, 2000GC000136, 2001.

Gente, P., R.A . Pockalny, C. Durand, C. Deplus, M. Maia, G. Ceuleneer, C. Mével, M. Cannat, and C. Laverne, Characteristics and evolution of the segmentation of the Mid-Atlantic Ridge between $20^{\circ} \mathrm{N}$ and $24^{\circ} \mathrm{N}$ during the last 10 million years, Earth and Planetary Science Letters, 129 (1-4), 55-71, 1995.

Gillis, K. M., and M. D. Roberts, Cracking at the magma-hydrothermal transition: evidence from the Troodos Ophiolite, Cyprus, Earth and Planetary Science Letters, 169, 227-244, 1999.

Goetze, C., The mechanism of solid state creep, Philosophical Transactions of the Royal Society of London, Series A, 288, 99-119, 1978.

Goetze, C., and B. Evans, Stress and temperature in the bending lithosphere as constrained by experimental rock mechanics, Geophysical Journal of the Royal Astronomical Society, 59, 463-478, 1979.

Goff, J. A., Quantitative characterization of abyssal hill morphology along flow lines in the Atlantic Ocean, Journal of Geophysical Research, 97, 9183-9202, 1992.

Grindlay, N. R., P. J. Fox, and K. C. Macdonald, Second-order ridge axis discontinuities in the South Atlantic: Morphology, structure, and evolution, Marine Geophysical Researches, 13, 21-49, 1991.

Grindlay, N. R., P. J. Fox, and P. R. Vogt, Morphology and tectonics 
of the Mid-Atlantic Ridge $\left(25^{\circ}-27^{\circ} 30^{\prime} \mathrm{S}\right)$ from Sea Beam and magnetic data, Journal of Geophysical Research, 97 (B5), 6983-7010, 1992.

Hammond, W. C., and D. R. Toomey, Seismic velocity anisotropy and heterogeneity beneath the Mantle Electromagnetic and Tomography Experiment (MELT) region of the East Pacific Rise from the analysis of P and S body waves, Journal of Geophysical Research, 108 (B4), ESE1, doi:10.1029/2002JB001789, citation no. 2176, 2003.

Hekinian, R., Rocks from the mid-oceanic ridge in the Indian ocean, Deep-Sea Research, 15, 195-213, 1968.

Henstock, T., A. Woods, and R. White, The accretion of oceaniccrust by episodic sill intrusion, Journal of Geophysical Research, 98 (B3), 4143-4161, 1993.

Hirth, G., Laboratory constraints on the rheology of the upper mantle, in Plastic Deformation of Minerals and Rocks, edited by H. R. Wenk, pp. 97-120, 2002.

Hirth, G., J. Escartin, and J. Lin, The rheology of the lower oceanic crust: Implications for lithospheric deformation at mid-ocean ridges, in Faulting and Magmatism at Mid-Ocean Ridges, Geophysical Monograph 106, edited by W. R. Buck, P. T. Delaney, J. A. Karson, and Y. Lagabrielle, pp. 291-303, American Geophysical Union, Washington, D.C., 1998.

Hirth, G., and D. L. Kohlstedt, Experimental constraints on the dynamics of the partially molten upper mantle 2 . Deformation in the dislocation creep regime, Journal of Geophysical Research, 100 (B8), 15,441-15,449, 1995a.

Hirth, G., and D. L. Kohlstedt, Experimental constraints on the dynamics of the partially molten upper-mantle-Deformation in the diffusion creep regime, Journal of Geophysical Research-Solid Earth, 100 (B2), 1981-2001, 1995 b.

Hirth, G., and D. L. Kohlstedt, Water in the oceanic upper mantle: implications for rheology, melt extraction and the evolution of the lithosphere, Earth and Planetary Science Letters, 144, 93-108, 1996.

Hirth, G., and D. L. Kohlstedt, Rheology of the upper mantle and the mantle wedge: a view from the experimentalists, in The Subduction Factory, edited by J. M. Eiler, in press.

Hooft, E. E. E., R. S. Detrick, D. R. Toomey, J. A. Collins, and J. Lin, Crustal thickness and structure along three contrasting spreading segments of the Mid-Atlantic Ridge, $33.5^{\circ}-35^{\circ} \mathrm{N}$, Journal of Geophysical Research, B, 105, 8205-8226, 2000.

Horen, H., M. Zamora, and G. Dubuisson, Seismic waves velocities and anisotropy in serpentinized peridotites from Xigaze ophiolite: abundance of serpentine in slow spreading ridges, Geophysical Research Letters, 23 (1), 9-12, 1996.

Hosford, A., J. Lin, and R. S. Detrick, Crustal evolution over the last 2 m.y. at the Mid-Atlantic Ridge $\mathrm{OH}-1$ segment, $35^{\circ} \mathrm{N}$, Journal of Geophysical Research, 106 (B7), 13,269-13,285, 2001.

Huang, P. Y., and S. C. Solomon, Centroid depths of mid-ocean ridge earthquakes: Dependence on spreading rate, Journal of Geophysical Research, 93, 13445-13477, 1988.

Jaoul, O., J. Tullis, and A. Kronenberg, The effect of varying water contents on the creep behavior of Heavitree quartzite, Journal of Geophysical Research, 89 (B6), 4298-4312, 1984.

Jaroslow, G. E., The geological record of oceanic crustal accretion and tectonism at slow-spreading ridges, $\mathrm{Ph} . \mathrm{D}$. thesis, MIT/WHOI 97-09, 1996.

Jaroslow, G. E., G. Hirth, and H. J. B. Dick, Abyssal peridotite mylonites: Implications for grain-size sensitive flow and strain localization in the oceanic lithosphere, Tectonophysics, 256 (1-4), 17-37, 1996.

Jokat, W., O. Ritzman, M. C. Schmidt-Aursch, S. Drachev, S. Gauger, and J. E. Snow, Geophysical evidence for reduced melt production on the Arctic ultraslow Gakkel mid-ocean ridge, Nature, 423, 962-965, 2003.

Juteau, T., E. Berger, and M. Cannat, Serpentinized, residual mantle peridotites from the M.A.R. median valley, ODP hole 670A $\left(21^{\circ} 10^{\prime} \mathrm{N}, 45^{\circ} 02^{\prime} \mathrm{W}\right.$, leg 109$)$ : primary mineralogy and geothermometry, in Proceedings of the Ocean Drilling Program, Scientific Results, edited by R. Detrick, J. Honnorez, W.B. Bryan, and T. Juteau, pp. 27-45, College Station, Texas, 1990.

Karato, S.-I., M. S. Paterson, and J. D. Fitzgerald, Rheology of synthetic olivine aggregates: Influence of grain size and water, Journal of Geophysical Research, 91 (B8), 8151-8176, 1986.

Karson, J. A., Seafloor spreading on the Mid-Atlantic Ridge: implications for the structure of ophiolites and oceanic lithosphere produced in slow-spreading environments, in Proceedings of the Symposium on Ophiolites and Oceanic Lithosphere-TROODOS 87, edited by J. Malpas, E. M. Moores, A. Panayyiotou, and C. Xenophontos, pp. 547-555, Geological Survey Department, Ministry of Agriculture and Natural Resources, Nicosia, Cyprus, 1990.

Karson, J. A., Internal structure of oceanic lithosphere: A perspective from tectonic windows, in Faulting and Magmatism at Mid-Ocean Ridges: Geophysical Monograph 106, edited by W. R. Buck, P. T. Delaney, J. A. Karson, and Y. Lagabrielle, pp. 177-218, American Geophysical Union, Washington, DC, 1998.

Karson, J. A., and H. J. B. Dick, Tectonics of ridge-transform intersections at the Kane Fracture Zone, Marine Geophysical Researches, 6, 51-98, 1983.

Karson, J. A., E. M. Klein, S. D. Hurst, C. E. Lee, P. Rivizzigno, D. Curewittz, and A. R. Morris, Structure of uppermost fast-spread oceanic crust exposed at the Hess Deep Rift: Implications for subaxial processes at the East Pacific Rise, Geochemistry, Geophysics and Geosystems, 3, i10.1029/2001GC000155, 2002.

Karson, J. A., and R. M. Lawrence, Tectonic setting of serpentinite exposures on the western median valley wall of the MARK area in the vicinity of site 920, Proceedings of the Ocean Drilling Program, Scientific Results, 153, 5-21, 1997.

Karson, J. A., G. Thompson, S. E. Humphris, J. M. Edmond, W. B. Bryan, J. R. Brown, A. T. Winters, R. A. Pockalny, J. R. Casey, C. A. C., G. Klinkhammer, M. R. Palmer, R. J. Kinzler, and M. M. Sulanowska, Along-axis variations in seafloor spreading in the MARK area, Nature, 328, 681-685, 1987.

Katsumata, K., T. Sato, J. Kasahara, N. Hirata, R. Hino, N. Takahashi, M. Sekine, S. Miura, S. Koresawa, and N. Wada, Microearthquake seismicity and focal mechanisms at the Rodriguez Triple Junction in the Indian Ocean using ocean bottom seismometers, Journal of Geophysical Research-Solid Earth, 106 (B12), 30689-30699, 2001.

Kelemen, P. B., and E. Aharonov, Periodic formation of magma frac- 
tures and generation of layered gabbros in the lower crust beneath oceanic spreading ridges, in Faulting and Magmatism at MidOcean Ridges-Geophysical Monograph 106, edited by W. R. Buck, P. T. Delaney, J. A. Karson, and Y. Lagabrielle, pp. 267-289, American Geophysical Union, Washington, D.C., 1998.

Kelemen, P. B., M. Braun, and G. Hirth, Spatial distribution of melt conduits in the mantle beneath oceanic spreading centers: Observations from the Ingalls and Oman ophiolites, Geochemistry, Geophysics, Geosystems, 1, 1999GC000012, 2000.

Kent, G. M., S. C. Singh, A. J. Harding, M. C. Sinha, J. A. Orcutt, P. J. Barton, R. S. White, S. Bazin, R. W. Hobbs, C. H. Tong, and J. W. Pye, Evidence from three-dimensional seismic reflectivity images for enhanced melt supply beneath mid-ocean-ridge discontinuities, Nature, 406, 614-618, 2000.

Kirby, S. H., Rheology of the lithosphere, Reviews of Geophysics, 21 (6), 1458-1487, 1983.

Kirby, S. H., and A. K. Kronenberg, Deformation of clinopyroxene: Evidence for a transition in flow mechanisms and semibrittle behaviour, Journal of Geophysical Research, 89 (B5), 3177-3192, 1984.

Kleinrock, M. C., B. E. Tucholke, J. Lin, and M. A. Tivey, Fast rift propagation at a slow-spreading ridge, Geology, 25 (7), 639-642, 1997.

Kohlstedt, D. J., and C. Goetze, Low-stress high-temperature creep in olivine single crystals, Journal of Geophysical Research, 74 (14), 2045-2051, 1974.

Kohlstedt, D. L., Q. Bai, Z.-C. Wang, and S. Mei, Rheology of partially molten rocks, in Physics and Chemistry of Partially Molten Rocks, edited by A. B. Thompson, pp. 3-28, Kluwer, 2000.

Kohlstedt, D. L., B. Evans, and S. J. Mackwell, Strength of the lithosphere: Constraints imposed by laboratory experiments, Journal of Geophysical Research, 100 (B9), 17,587-17,602, 1995.

Kong, L. S. L., S. C. Solomon, and G. M. Purdy, Microearthquake characteristics of a Midocean Ridge Along-Axis High, Journal of Geophysical Research, 97 (B2), 1659-1685, 1992.

Kronenberg, A., and J. Tullis, Flow strengths of quartz aggregates: grain size and pressure effects due to hydrolitic weakening, Journal of Geophysical Research, 89 (B6), 4281-4297, 1984.

Kuo, B. Y., and D. W. Forsyth, Gravity anomalies of the ridge-transform system in the South Atlantic between 31 and $34.5^{\circ} \mathrm{S}$ : Upwelling centers and variations in crustal thickness, Marine Geophysical Researches, 10 (3-4), 205-232, 1988.

Kuo, B. Y., D. W. Forsyth, and E. M. Parmentier, Flexure and thickening of the lithosphere at the East Pacific Rise, Geophysical Research Letters, 13, 681-684, 1986.

Kurewitz, D., and J. A. Karson, Structural settings of hydrothermal outflow: Fracture permeability maintained by fault propagation and interaction, Journal of Volcanology and Geothermal Research, 79, 149-168, 1997.

Lagabrielle, Y., D. Bideau, M. Cannat, J. A. Karson, and C. Mevel, Ultramafic-mafic plutonic rock suites exposed along the MidAtlantic Ridge $\left(10^{\circ} \mathrm{N}-30^{\circ} \mathrm{N}\right)$. Symmetrical-asymmetrical distribution and implications for seafloor spreading processes, in Faulting and Magmatism at Mid-Ocean Ridges: Geophysical Monograph no. 106, edited by W. R. Buck, P. T. Delaney, J. A. Karson, and Y. Lagabrielle, pp. 153-176, American Geophysical
Union, Washington, D.C., 1998.

Lavier, L. L., W.R . Buck, and A. N. B. Poliakov, Self-consistent rolling-hinge model for the evolution of large-offset low-angle normal faults, Geology, 27 (12), 1127-1130, 1999.

Lawson, K., R. C. Searle, J. A. Pearce, P. Browning, and P. Kempton, Detailed volcanic geology of the MARNOK area, Mid-Atlantic Ridge north of Kane transform, in Tectonic, Magmatic, Hydrothermal and Biological Segmentation of Mid-Ocean Ridges, Geol. Soc. London, Spec. Publ. 118, edited by C. J. MacLeod, P. A. Tyler, and C. L. Walker, pp. 61-102, Geological Society, London, 1996.

Leeds, A. K., E. Kausel, and L. Knopoff, Variations of upper mantle structure under the Pacific Ocean, Science, 186 (141-143), 1974.

Lilwall, R. C., T. J. G. Francis, and P. I. T., A microearthquake survey at the junction of the East Pacific Rise and the Wilkes $\left(9^{\circ} \mathrm{S}\right)$ fracture zone, Geophysical Journal of the Royal Astronomical Society, 66, 407-416, 1981.

Lin, J., H. J. B. Dick, and H. Schouten, Evidence for highly focussed magmatic accretion along the ultra-slow Southwest Indian Ridge, Eos Transactions, American Geophysical Union, 84 (46, Fall Meeting Supplement), Abstract T11B-03, 2003.

Lin, J., and E. M. Parmentier, Mechanisms of lithospheric extension at mid-ocean ridges, Geophysical Journal, 96, 1-22, 1989.

Lin, J., and J. Phipps Morgan, The spreading rate dependence of three-dimensional mid-ocean ridge gravity structure, Geophysical Research Letters, 19 (1), 13-16, 1992.

Lin, J., G.M. Purdy, H. Schouten, J.-C. Sempéré, and C. Zervas, Evidence from gravity data for focused magmatic accretion along the Mid-Atlantic Ridge, Nature, 344, 627-632, 1990.

Louden, K. E., R. S. White, C. G. Potts, and D. W. Forsyth, Structure and seismotectonics of the Vema Fracture Zone, Atlantic Ocean, Journal of the Geological Society of London, 143, 795-805, 1986.

Macdonald, K. C., in Faulting and Magmatism at Mid-Ocean Ridges, Geophysical Monograph 106, edited by W. R. Buck, P. T. Delaney, J. A. Karson, and Y. Lagabrielle, American Geophysical Union, Washington, D.C., 1998.

Macdonald, K. C., P. J. Fox, S. Carbotte, M. Eisen, S. Miller, L. Perram, D. Scheirer, S. Tighe, and C. Weiland, The East Pacific Rise and its Flanks $8-17^{\circ} \mathrm{N}$ : History of Segmentation, Propagation and Spreading Direction Based on SeaMARC II and Seabeam Studies, 1991a.

Macdonald, K. C., and B. P. Luyendyk, Deep-tow studies of the structure of the Mid-Atlantic ridge crest near $37^{\circ} \mathrm{N}$ (FAMOUS), Geological Society of America Bulletin, 88, 621-636, 1977.

Macdonald, K. C., D. S. Scheirer, and S. M. Carbotte, Mid-Ocean Ridges: Discontinuities, segments and giant cracks, Science, 253, 986-994, 1991b.

Macdonald, K. C., J.-C. Sempere, and P. J. Fox, Reply: The debate concerning overlapping spreading centers and mid-ocean ridge processes, Journal of Geophysical Research, 91, 10501-10510, 1986.

Mackwell, S. J., M.E . Zimmerman, and D. L. Kohlstedt, High-temperature deformation of dry diabase with application to tectonics on Venus, Journal of Geophysical Research, 103 (B1), 975-984, 1998.

MacLeod, C. J., J. Escartin, D. Banerji, G. J. Banks, M. Gleeson, D. 
H. B. Irving, R. M. Lilly, A. M. McCaig, Y. Niu, S. Allerton, and D. K. Smith, Direct geological evidence for oceanic detachment faulting: The Mid-Atlantic Ridge, $15^{\circ} 45^{\prime} \mathrm{N}$, Geology, 30, 879-882, 2002.

MacLeod, C. J., and C. E. Manning, Influence of axial segmentation on hydrothermal circulation at fast-spreading ridges: insights from Hess Deep, in Tectonic, hydrothermal and biological segmentation at Mid-Ocean Ridges, edited by C. J. MacLeod, P. A. Tyler, and C. L. Walker, pp. in press, Geological Society, London, 1996.

MacLeod, C. J., and G. Yaouancq, A fossil melt lens in the Oman ophiolite: Implications for magma chamber processes at fast spreading ridges, Earth and Planetary Science Letters, 176 (3-4), 357-373, 2000.

Madsen, J. A., R. S. Detrick, J. C. Mutter, P. Buhl, and J. A. Orcutt, A two- and three-dimensional analysis of gravity anomalies associated with the East Pacific Rise at $9^{\circ} \mathrm{N}$ and $13^{\circ} \mathrm{N}, J$. Geophys. Res., 95, 4967-4987, 1990.

Madsen, J. A., D. W. Forsyth, and R. S. Detrick, A new isostatic model for the East Pacific Rise Crest, Journal of Geophysical Research, 89, 9997-10015, 1984.

Magde, L. S., A. H. Barclay, D. R. Toomey, R. S. Detrick, and J. A. Collins, Crustal magma plumbing within a segment of the MidAtlantic Ridge, $35^{\circ} \mathrm{N}$, Earth and Planetary Science Letters, 175 , 55-67, 2000.

Magde, L. S., and D. W. Sparks, Three-dimensional mantle upwelling, melt generation, and melt migration beneath segment slow spreading ridges, Journal of Geophysical Research, B, 102 (9), 20,571-20,583, 1997.

Magde, L. S., D. W. Sparks, and R. S. Detrick, The relationship between buoyant mantle flow, melt migration, and gravity bull's eyes at the Mid-Atlantic Ridge between $33^{\circ} \mathrm{N}$ and $35^{\circ} \mathrm{N}$, Earth and Planetary Science Letters, 148 (1-2), 59-, 1997.

Mainprice, D. H., and M. S. Paterson, Experimental studies of the role of water in the plasticity of quartzites, Journal of Geophysical Research, 89 (B6), 4257-4269, 1984.

Manning, C. E., and C. J. MacLeod, Fracture-controlled metamorphism of Hess Deep gabbros, site 894: Constraints on the roots of mid-ocean-ridge hydrothermal systems at fast-spreading centers, in Proc. of the Ocan Drilling Program Sci. Res., edited by C. Mével, K. M. Gillis, J. F. Allan, and P. S. Meyer, pp. 189-212, Ocean Drilling Program, College Station, TX, 1996.

Manning, C. E., C. J. MacLeod, and P. Weston, Lower-crustal cracking front at fast-spreading ridges: Evidence from the East Pacific Rise and the Oman ophiolite, in Ophiolites and the oceanic crust: New insights from field studies and the Ocean Drilling Program, edited by Y. Dilek, E. M. Moores, D. Elthon, and A. Nicolas, pp. 262-272, Geological Society of America, Boulder, Colorado, 2000.

Mares, V. M., and A. K. Kronenberg, Experimental deformation of muscovite, Journal of Structural Geology, 15 (9/10), 1061-1075, 1993.

McAllister, E., and J. Cann, Initiation and evolution of boundary wall faults along the Mid-Atlantic Ridge, $25-29^{\circ} \mathrm{N}$, in Tectonic, Magmatic, Hydrothermal and Biological Segmentation of MidOcean Ridges, edited by C. J. MacLeod, P. A. Tyler, and C. L.
Walker, pp. 29-48, Geological Society Special Publication 118, London, 1996.

McAllister, E., J. Cann, and S. Spencer, The evolution of crustal deformation in an oceanic extensional environment, Journal of Structural Geology, 17 (2), 183-199, 1995.

McKenzie, D. P., and C. O. Bowin, The relationship between bathymetry and gravity in the Atlantic Ocean, Journal of Geophysical Research, 81 (1903-1915), 1976.

McNutt, M. K., Lithospheric Flexure and Thermal Anomalies, Journal of Geophysical Research, 89 (B13), 11,180-11,194, 1984.

McNutt, M. K., and H. W. Menard, Constraints on Yield Strength in the Oceanic Lithosphere Derived from Observations of Flexure, Geophysical Journal of the Royal Astronomical Society, 71 (2), 363-394, 1982.

Mei, S., and D. L. Kohlstedt, Influence of water on plastic deformation of olivine aggregates. 1. Diffusion creep regime, Journal of Geophysical Research, 105 (B9), 21457-21469, 2000a.

Mei, S., and D. L. Kohlstedt, Influence of water on plastic deformation of olivine aggregates. 2. Dislocation creep regime, Journal of Geophysical Research, 105 (B9), 21471-21481, 2000b.

Melson, W .G., V. T. Bowen, T. H. Van Andel, and R. Siever, Greenstones from the central valley of the Mid-Atlantic Ridge, Nature, 209, 604-605, 1966.

MELT, Imaging the deep seismic structure beneath a mid-ocean ridge: The MELT experiment, Science, 280, 1215-18, 1998.

Mével, C., M. Cannat, P. Gente, E. Marion, J.-M. Auzende, and J. Karson, Emplacement of deep crustal and mantle rocks on the west median valley wall of the MARK area (MAR, $\left.23^{\circ} \mathrm{N}\right)$, Tectonophysics, 190 (192-210), 1991.

Mével, C., and C. Stamoudi, Hydrothermal alteration of the uppermantle section at Hess Deep, Proc. Ocean Drill. Prog., 147, 293-309, 1996.

Michael, P. J., C. H. Langmuir, H. J. B. Dick, J. E. Snow, S. L. Goldstein, D. W. Graham, K. Lehnert, G. J. Kurras, W. Jokat, R. Mühe, and H. N. Edmonds, Magmatic and amagmatic seafloor generation at the utraslow-spreading Gakkel ridge, Arctic Ocean, Nature, 423 (26), 956-962, 2003.

Minshull, T., and P. Charvis, Ocean island densities and models of lithospheric flexure, Geophysical Journal International, 145, 731-739, 2001.

Mitchell, N. C., J. Escartin, and S. Allerton, Detachment faults at mid-ocean ridges, EOS, Transactions of the American Geophysical Union, 79, 127, 1998.

Montesi, L. G. J., and G. Hirth, Grain size evolution and the rheology of ductile shear zones: from laboratory experiments to postseismic creep, Earth and Planetary Science Letters, 211, 97-110, 2003.

Neumann, G. A., and D. W. Forsyth The paradox of the axial profile: Isostatic compensation along the axis of the Mid-Atlantic Ridge?, Journal of Geophysical Research, 98 (B10), 17,891-17,910, 1993.

Neumann, G. A., D. W. Forsyth, and D. Sandwell, Comparison of marine gravity from shipboard and high-density satellite altimetry along the Mid-Atlantic Ridge, $30.5^{\circ}-35.5^{\circ} \mathrm{S}$, Geophysical Research Letters, 20 (15), 1639-1642, 1993.

Nishimura, C. E., and D. W. Forsyth, The anisotropic structure of the upper mantle in the Pacific, Geophysical Journal, 96, 203-229, 
1989.

Ohara, Y., T. Yoshida, Y. Kato, and S. Kasuga, Giant megamullion in the Parece Vela Backarc Basin, Marine Geophysical Researches, 22 (1), 47-61, 2001.

Parsons, B., and D. P. McKenzie, Mantle convection and the thermal structure of the plates, Journal of Geophysical Research, 83, 4,485-4,496, 1978.

Parsons, B., and J. G. Sclater, An analysis of the variation of ocean floor bathymetry and heat flow with age, Journal of Geophysical Research, 82, 803-827, 1977.

Phipps Morgan, J., and Y. J. Chen, Dependence of ridge-axis morphology on magma supply and spreading rate, Nature, 364 (19 August), 706-708, 1993.

Phipps Morgan, J., and E. M. Parmentier, Causes and rate-limiting mechanism of ridge propagations: A fracture mechanics model, Journal of Geophysical Research, 90, 8603-8612, 1985.

Phipps Morgan, J., and D. T. Sandwell, Systematics of ridge propagation south of $30^{\circ} \mathrm{S}$, Earth and Planetary Science Letters, 121, 245-258, 1994.

Phipps-Morgan, J., and Y. J. Chen, The genesis of oceanic crust: Magma injection, hydrothermal circulation, and crustal flow, Journal of Geophysical Research, 98 (B4), 6283-6297, 1993.

Poliakov, A. N. B., and W. R. Buck, Mechanics of stretching elasticplastic-viscous layers: Applications to slow-spreading mid-ocean ridges, in Faulting and Magmatism at Mid-Ocean Ridges, edited by W. R. Buck, P. T. Delaney, J. A. Karson, and Y. Lagabrielle, pp. 305-323, American Geophysical Union, Washington, D.C., 1998.

Pollard, D. D., and A. Aydin, Propagation and linkage of oceanic ridge segments Journal of Geophysical Research, 89, 10017-10028, 1984.

Prinz, M., K. Keil, A. Gree, A.M. Reid, E. Bonatti, and J. Honnorez, Ultramafic and mafic dredge samples from the equatorial midAtlantic ridge and fracture zones, Journal of Geophysical Research, 81 (23), 4087-4103, 1976.

Purdy, G. M., J.-C. Sempere, H. Schouten, D. L. DuBois, and R. Goldsmith, Bathymetry of the Mid-Atlantic Ridge, $24^{\circ}-31^{\circ} \mathrm{N}$ : A map series, Marine Geophysical Researches, 12, 247-252, 1990.

Quick, J. E., and R. P. Delinger, Ductile deformation and the origin of layered gabbro in ophiolites, Journal of Geophysical Research, 98 (B8), 14015-14027, 1993.

Rabain, A., M. Cannat, J. Escartin, G. Pouliquen, C. Deplus, and C. Rommevaux-Jestin, Focused volcanism and growth of a slow spreading segment (Mid-Atlantic Ridge, $35^{\circ} \mathrm{N}$ ), Earth and Planetary Science Letters, 185 (1-2), 211-224, 2001.

Ranero, C. R., and T. J. Reston, Detachment faulting at ocean core complexes, Geology, 27 (11), 983-986, 1999.

Reinen, L. A., J. D. Weeks, and T. E. Tullis, The frictional behavior of lizardite and antigorite serpentinites: experiments, constitutive models, and implications for natural faults, Pure and Applied Geophysics, 143 (1/2/3), 318-358, 1994.

Renner, J., B. Evans, and G. Hirth, On the rheologically critical melt fraction, Earth and Planetary Science letters, 181, 585-594, 2000.

Reston, T. J., W. Weinrebe, I. Grevemeyer, E. R. Flueh, N. C. Mitchell, L. Kirstein, C. Kopp, and H. Kopp, A rifted inside corner massif on the Mid-Atlantic Ridge at $5^{\circ} \mathrm{S}$, Earth and Planetary Science Let- ters, 200 (3-4), 255-269, 2002.

Rommevaux-Justin, C., C. Deplus, and P. Patriat, Mantle Bouguer anomaly along an ultra slow-spreading ridge: Implications for accretionary processes and comparison with results from central Mid-Atlantic Ridge, Marine Geophysical Researches, 19 (6), 481-503, 1997.

Rutter, E. H., and K. H. Brodie, The role of grain size reduction in the rheological stratification of the lithosphere, Geologische Rundschau, 77 (1), 295-308, 1988.

Rybacki, E., and G. Dresen, Dislocation and diffusion creep of synthetic anorthite aggregates, Journal of Geophysical Research, 105 (B11), 26017-26036, 2000.

Scholz, C. H., The brittle-plastic transition and the depth of seismic faulting, Geologische Rundschau, 77 (1), 319-328, 1988.

Schouten, H., K. D. Klitgord, and J. A. Whitehead, Segmentation of mid-ocean ridges, Nature, 317, 225-229, 1985.

Searle, R. C., GLORIA survey of the East Pacific Rise near $3.5^{\circ} \mathrm{S}$ : tectonic and volcanic characteristics of a fast-spreading mid-ocean rise, Tectonophysics, 101, 319-344, 1984.

Searle, R. C., The volcano-tectonic setting of oceanic lithosphere generation, in Ophiolites and their modern oceanic analogues, edited by L. M. Parson, B. J. Murton, and P. Browning, pp. 65-80, Geological Society of London, 1992.

Searle, R. C., M. Cannat, K. Fujioka, C. Mevel, H. Fujimoto, A. Bralee, and L. Parson, The FUJI Dome: A large detachment fault near $64^{\circ} \mathrm{E}$ on the very slow-spreading southwest Indian Ridge, Geochemistry, Geophysics, Geosystems, 4 (8), 9105, doi:10.1029/2003GC000519, 2003.

Searle, R. C., P. A. Cowie, S. Allerton, J. Escartin, P. Meredith, N. Mitchell, J. R. Cann, D. Blackman, E. McAllister, D. Smith, B. E. Tucholke, and J. Lin, Bending and Breaking the Ocean Floor, BRIDGE Newsletter, 17, 18-20, 1999.

Searle, R. C., P. A. Cowie, N. C. Mitchell, S. Allerton, C. J. MacLeod, J. Escartin, S. M. Russell, P. A. Slootweg, and T. Tanaka, Fault structure and detailed evolution of a slow spreading ridge segment: the Mid-Atlantic Ridge at $29^{\circ} \mathrm{N}$, Earth and Planetary Science Letters, 154 (1-4), 167-183, 1998a.

Searle, R. C., J. A. Keeton, S. M. Lee, R. Owens, R. Mecklenburgh, B. Parsons, and R. S. White, The Reykjanes Ridge: structure and tectonics of a hot-spot influenced, slow-spreading ridge, from multibeam bathymetric, gravity and magnetic investigations, Earth and Planetary Science Letters, 160, 463-478, 1998b.

Sempéré, J.-C., P. Blondel, A. Briais, T. Fujiwara, L. Geli, N. Isezaki, J. E. Pariso, L. Parson, P. Patriat, and C. Rommevaux, The MidAtlantic Ridge between $29^{\circ} \mathrm{N}$ and $31^{\circ} 30$ ' $\mathrm{N}$ in the last $10 \mathrm{Ma}$, Earth and Planetary Science Letters, 130 (1-4), 45-55, 1995.

Severinghaus, J. P., and K. C. Macdonald, High inside corners at ridge-transform intersections, Marine Geophysical Researches, 9, 353-367, 1988.

Shaw, P., Ridge segmentation, faulting and crustal thickness in the Atlantic Ocean, Nature, 358, 490-493, 1992.

Shaw, P. R., and J. Lin, Causes and consequences of variations in faulting style at the Mid-Atlantic Ridge, Journal of Geophysical Research, 98 (B12), 21,839-21,851, 1993.

Shaw, W. J., and J. Lin, Models of ocean ridge lithospheric deformation: Dependence on crustal thickness, spreading rate, and seg- 
mentation, Journal of Geophysical Research, 101 (B8), 17,977-17,993, 1996.

Shea, W. T., and A. K. Kronenberg, Rheology and deformation mechanisms of an isotropic mica schist, Journal of Geophysical Research, 97 (B11), 15201-15237, 1992.

Shea, W. T., and A. K. Kronenberg, Strength and anisotropy of foliated rocks with varied mica contents, Journal of Structural Geology, 15 (9/10), 1097-1121, 1993.

Shelton, G. L., and J. Tullis, Experimental flow laws for crustal rocks, EOS, Transactions of the American Geophysical Union, 62, 396, 1981.

Shipboard Scientific Party, Site 504, in Proceedings of the Ocean Drilling Program, Initial Reports, vol 148, edited by J. Alt, H. Kinoshita, and L. Stokking, pp. 27-121, Ocean Drilling Program, College Station, TX, 1993.

Shipboard Scientific Party, Ocean Drilling Program, Site 504B, Ocean Drilling Program, College Station, TX, 1995.

Shipboard Scientific Party, Leg 209 Preliminary Report: Drilling Mantle Peridotite along the Mid-Atlantic Ridge from $14^{\circ}$ to $16^{\circ} \mathrm{N}$, 6 May 2003-6 July 2003, pp. 100 + figures, Ocean Drilling Program, Texas A\&M University, College Station TX 77845-9547, 2003

Sinha, M., and R. L. Evans, Geophysical constraints on the thermal regime of the oceanic crust, in InterRidge Theoretical Institute: Thermal Regime of Ocean Ridges and Dynamics of Hydrothermal Circulation, edited by C. German, J. Lin, R. Tribuzio, A. Fisher, M. Cannat, and A. Adamczewska, pp. 18, InterRidge, Pavia, 2003.

Solomon, S. C., P. Y. Huang, and L. Meinke, The seismic moment budget of slowly spreading ridges, Nature, 298, 149-151, 1988.

Sparks, D. W., and E. M. Parmentier, The structure of three-dimensional convection beneath oceanic spreading centres, Geophysical Journal International, 112, 81-91, 1993.

Stein, C. A., and S. Stein, A model for the global variation in oceanic depth and heat flow with lithospheric age, Nature, 359, 123-129, 1992.

Tapponnier, P., and J. Francheteau, Necking of the lithosphere and the mechanics of slowly accreting plate boundaries, Journal of Geophysical Research, 83, 3955-3970, 1978.

Taylor, B., K. Crook, and J. Sinton, Extensional transform zones and oblique spreading centers, Journal of Geophysical Research, B, 99 (10), 19,707-19,718, 1994.

Thibaud, R., P. Gente, and M. Marcia, A systematic analysis of the Mid-Atlantic Ridge morphology and gravity between $15^{\circ} \mathrm{N}$ and $40^{\circ} \mathrm{N}$ : Constraints of the thermal structure, Journal of Geophysical Research, 103 (B10), 24201-24221, 1998.

Tolstoy, M., A. J. Harding, and J. A. Orcutt, Crustal thickness on the Mid-Atlantic Ridge-Bull's-eye gravity-anomalies and focused accretion, Science, 262 (5134), 726-729, 1993.

Tolstoy, M., F. L. Vernon, J. A. Orcutt, and F. K. Wyatt, Breathing of the seafloor: Tidal correlations of seismicity at Axial volcano, Geology, 30 (6), 503-506, 2002.

Toomey, D. R., S. C. Solomon, and G. M. Purdy, Microearthquakes beneath the median valley of the Mid-Atlantic Ridge near $23^{\circ} \mathrm{N}$ : Tomography and tectonics, Journal of Geophysical Research, 93 (B8), 9093-9112, 1988.

Toomey, D. R., S. C. Solomon, G. M. Purdy, and M. H. Murray,
Microearthquakes beneath the median valley of the Mid-Atlantic Ridge near $23^{\circ} \mathrm{N}$ : Hypocenters and focal mechanisms, Journal of Geophysical Research, 90, 5443-5458, 1985.

Tucholke, B., J. Lin, and M. Kleinrock, Megamullions and mullion structure defining oceanic metamorphic core complexes on the Mid-Atlantic Ridge, Journal of Geophysical Research, B, 103 (5), 9857-9866, 1998.

Tucholke, B., J. Lin, M. Kleinrock, M. Tivey, T. Reed, J. Goff, and G. Jaroslow, Segmentation and crustal structure of the western MidAtlantic Ridge flank, $25^{\circ} 25^{\prime}-27^{\circ} 10^{\prime} \mathrm{N}$ and 0-29 m.y., Journal of Geophysical Research, 102 (B5), 10,203-10,223, 1997.

Tucholke, B. E., W. R. Buck, L. Lavier, and J. Lin, Investigation of megamullion formation in relation to magma supply, Geophysical Research Abstracts, 5, EAE03-A-07925, 2003.

Tucholke, B. E., K. Fujioka, T. Ishihara, G. Hirth, and M. Kinoshita, Submersible study of an oceanic megamullion in the central North Atlantic, Journal of Geophysical Research, B, 106, 16,145-16,161, 2001.

Tucholke, B. E., and J. Lin, A geological model for the structure of ridge segments in slow spreading ocean crust, Journal of Geophysical Research, 99, 11,937-11,958, 1994.

Tullis, J., and R. Yund, Hydrolitic weakening of quartz aggregates: the effects of water and pressure on recovery, Geophysical Research Letters, 16 (11), 1343-1346, 1989.

Tullis, J., and R. Yund, Diffusion creep in felspar aggregates: experimental evidence, Journal of Structural Geology, 13 (9), 987-1000, 1991.

Tullis, J., and R. Yund, The brittle-ductile transition in felspar aggregates: an experimental study, in Fault mechanics and transport properties of rock, edited by B. Evans, and T. F. Wong, pp. 89-117, Academic Press, 1992.

Tullis, J., and R. A. Yund, Experimental deformation of dry Westerly granite, Journal of Geophysical Research, 82 (36), 5705-5718, 1977.

Van der Wal, D., Deformation process in mantle peridotites with emphasis on the Ronda peridotite of SW Spain, Geologica Ultraiectina, 102, 1-180, 1993.

Vera, E. E., J. C. Mutter, P. Buhl, J. A. Orcutt, A. J. Harding, M. E. Kappus, R. S. Detrick, and T. M. Brocher, The Structure of 0- to 0.2-m.y.-old oceanic crust at $9^{\circ} \mathrm{N}$ on the East Pacific Rise from expanded spread profiles, Journal of Geophysical Research, 95, 15529-15556, 1990.

Wang, X., and J. R. Cochran, Gravity anomalies, isostasy, and mantle flow at the East Pacific Rise crest, Journal of Geophysical Research, 98, 19,505-19,532, 1993.

Watts, A., and S. Zhong, Observations of flexure and the rheology of oceanic lithosphere, Geophysical Journal International, 142, 855-875, 2000.

Watts, A. B., An analysis of isostasy in the worlds oceans: 1. Hawaiian-Emperor seamount chain, Journal of Geophysical Research, 83 (5989-6004), 1978.

Weissel, J. K., and D. E. Hayes, The Australian-Antarctic discordance: new results and implications, Journal of Geophysical Research, 79, 2579-2587, 1974.

Weissel, J. K., and G. D. Karner, Flexural uplift of rift flanks due to mechanical unloading of the lithosphere during extension, Jour- 
nal of Geophysical Research, 94 (B10), 13,919-13,950, 1989.

West, B. P., J. Lin, and D. M. Christie, Forces driving ridge propagation, Journal of Geophysical Research-Solid Earth, 104 (B10), 22845-22858, 1999.

Whitehead, J. A., H. J. B. Dick, and H. Schouten, A mechanism for magmatic accretion under spreading centres, Nature, 312, 146-148, 1984.

Wiens, D. A., and S. Stein, Age dependence of oceanic intraplate seismicity and implications for lithospheric evolution, Journal of Geophysical Research, 88, 6455-6468, 1983.

Wilcock, W. S. D., S. D. Archer, and G. M. Purdy, Microearthquakes on the Endeavour segment of the Juan de Fuca Ridge, Journal of Geophysical Research, 107 (B12), EPM4, doi:10.1029/2001JB000505, 2002.

Wilcock, W. S. D., Purdy, and Solomon, Microearthquake evidence for extension across the Kane transform fault, Journal of Geophysical Research, B, 95 (10), 15,439-15,462, 1990.

Wilson, D. S., D. A. Clague, N. H. Sleep, and J. L. Morton, Impli- cations of magma convection for the size and temperature of magma chambers at fast spreading ridges, Journal of Geophysical Research, 93 (11,974-11,984), 1988.

Wolfe, C. J., G. M. Purdy, D. R. Toomey, and S. C. Solomon, Microearthquake characteristics and crustal velocity structure at $29^{\circ} \mathrm{N}$ on the Mid-Atlantic Ridge: The architecture of a slowspreading segment, Journal of Geophysical Research, 100 (B12), 24,449-24,472, 1995.

Yoshinobu, A. S., and G. Hirth, Microstructural and experimental constraints on the rheology of partially molten gabbro beneath oceanic spreading centers, Journal of Structural Geology, 24 (6-7), 1101-1107, 2002.

R. C. Searle, Department of Earth Sciences, University of Durham, DH1 3LE, UK, r.c.searle@durham.ac.uk

Escartín, Laboratoire de Géosciences Marines (CNRS UMR7097), Institut de Physique du Globe de Paris, France, escartin@ipgp.jussieu.fr 